\title{
Key to the adults of the most common forensic species of Diptera in South America
}

\author{
Claudio José Barros de Carvalho ${ }^{1}$ \& Cátia Antunes de Mello-Patiu²
}

\begin{abstract}
${ }^{1}$ Department of Zoology, Universidade Federal do Paraná, C.P. 19020, Curitiba-PR, 81.531-980, Brazil. cjbcarva@ufpr.br
\end{abstract} ${ }^{2}$ Department of Entomology, Museu Nacional do Rio de Janeiro, Rio de Janeiro-RJ, 20940-040, Brazil. camello@acd.ufrj.br

\begin{abstract}
Key to the adults of the most common forensic species of Diptera in South America. Flies (Diptera, blow flies, house flies, flesh flies, horse flies, cattle flies, deer flies, midges and mosquitoes) are among the four megadiverse insect orders. Several species quickly colonize human cadavers and are potentially useful in forensic studies. One of the major problems with carrion fly identification is the lack of taxonomists or available keys that can identify even the most common species sometimes resulting in erroneous identification. Here we present a key to the adults of 12 families of Diptera whose species are found on carrion, including human corpses. Also, a summary for the most common families of forensic importance in South America, along with a key to the most common species of Calliphoridae, Muscidae, and Fanniidae and to the genera of Sarcophagidae are provided. Drawings of the most important characters for identification are also included.
\end{abstract}

KEYWORDS. Carrion flies; forensic entomology; neotropical.

RESUMO. Chave de identificação para as espécies comuns de Diptera da América do Sul de interesse forense. Diptera (califorídeos, sarcofagídeos, motucas, moscas comuns e mosquitos) é a uma das quatro ordens megadiversas de insetos. Diversas espécies desta ordem podem rapidamente colonizar cadáveres humanos e são de utilidade potencial para estudos de entomologia forense. Um dos maiores problemas com moscas que visitam matéria orgânica animal em decomposição é a falta de taxonomistas ou chaves de identificação disponíveis que possam identificar as espécies mais comuns ou mesmo, algumas vezes podendo resultar em identificações errôneas. Neste artigo é apresentada uma chave para adultos de 12 famílias de Diptera com espécies encontradas em matéria orgânica animal em decomposição, incluindo cadáveres humanos. Também é incluído um sumário das mais importantes famílias com espécies de interesse forense na América do Sul e chave de identificação das espécies mais comuns de Calliphoridae, Muscidae e Fanniidae e dos gêneros de Sarcophagidae. Esquemas dos mais importantes caracteres utilizados para identificação dessas espécies são também incluídos.

PALAVRAS-CHAVE. Entomologia forense; moscas varejeiras; neotropical.

Diptera, one of the four megadiverse insect orders, are the best-catalogued insects in all biogeographic regions. True flies are cosmopolitan with about 150,000 described species in 158 families (Thompson 2006).

Commonly known as blow flies, house flies, flesh flies, horse flies, cattle flies, midges and mosquitoes, many fly species are important in medicine and hygiene for humans and livestock. They may be directly important for their interactions with humans and animals, or indirectly due to their affinities with faeces or decomposing organic materials, thereby being potential vectors of diseases. House flies, the best known group, have been cited since the Bible (Thompson $\&$ Pont 1994), while most flies are not in contact with man. However, flies are probably the most important insect group to humans. They are also the most important carrion insects, several species of which colonize human cadavers, and therefore, are potentially useful in forensic studies (Greenberg 1991; Turner 1991; Oliveira-Costa 2003).

An identification key for 23 families of Diptera with species that feed or oviposit on carrion or with larvae reared from carrion is found in the classic "A Manual of Forensic Entomology" (Smith 1986). In Brazil, species of 22 families of
Diptera are associated with carrion, seven of which (Calliphoridae, Muscidae, Fanniidae, Phoridae, Piophilidae, Sarcophagidae and Stratiomyidae) are of forensic importance (Carvalho et al. 2000). In a recent study of forensic entomology in Brazil, species in eight families, including the families mentioned above plus Drosophilidae, were considered of forensic importance (Leonardo Gomes \& Claudio von Zuben, personal communication).

Yet, two major problems with identification of carrion flies are the lack of taxonomists to identify the species as well as the lack of keys, even for the most common species. These two problems inevitably lead to occasional errors in identification. Before undertaking any study of a basic or practical nature, we must know with whom we are dealing. In other words, we must know Who is Whom (Carvalho 2002).

Here, we provide a key for the adults of 12 dipteran families that are necrophagic on humans or other animals. Eight of these families feed on human corpses and four -Anthomyiidae, Sepsidae, Sphaeroceridae, Ulidiidae (=Otitidae) - feed on animal carrion (Monteiro-Filho \& Penereiro 1987; Moura et al. 1997, 2005; Carvalho et al. 2000). A summary for the most important species, a key to the most common, forensically 
important, species in the families Calliphoridae, Muscidae, and Fanniidae and the genera of Sarcophagidae are also provided.

The terminology used for adult morphology follows McAlpine (1981) and Carvalho et al. (2002). It is important to note that these keys are specifically for species found on carrion or cadavers in South America, and are not for Diptera in general.

Key to South American families of Diptera with forensic importance

1. Antenna usually longer than thorax with six or more flagellomeres. Palpus usually with 3-5 segments. Body and legs usually elongated ..... Nematocera

Antenna usually shorter than thorax with fewer than six flagellomeres, the first one usually enlarged and distal modified to stylus or arista (Fig. 1). Palpus with 1-2 segments. Body and legs usually stronger (Brachycera)

2. Ptilinal fissure and lunule absent. $\mathrm{CuA}_{2}$ vein usually reaching wing margin or joining $\mathrm{A}_{1}$ vein near its apex (Fig. 2) .... 3

Ptilinal fissure and lunule present (Fig. 3). $\mathrm{CuA}_{2}$ vein usually joining $\mathrm{A}_{1}$ near wing base (Fig. 4) . .. 4

3. Empodia pulvilliform (Fig. 5). Antenna longer than head; terminal flagellomere flat and long sometimes longer than the other flagellomeres (Fig. 6). Wing with a small discal cell in the centre (Fig. 2) Stratiomyidae

Empodia usually setiform. Antenna short. Wing without discal cell; radial veins positioned in anterior margin and distinctly stronger than remaining veins .......... Phoridae

4. Antennal pedicel with a complete dorsal seam (Fig. 7). Greater ampulla present (Figs. 8, 9). Calypters usually well developed...

Antennal pedicel usually without dorsal seam. Greater ampulla absent. Calypters usually small or undeveloped

5. Meron (Fig. 9) without a row of setae; rarely with scattered weak setulae.

Meron with a row of setae (Fig. 10) ......

6. Scutellum usually with setulae on ventral apex (Fig. 11). Wing vein $\mathrm{A}_{1}+\mathrm{CuA}_{2}$ reaching wing margin. Hind leg with strong seta at lower base of first tarsomere

Anthomyiidae

Scutellum without setulae on ventral apex. Wing vein $\mathrm{A}_{1}+\mathrm{CuA}_{2}$ not reaching wing margin (Fig. 12). Hind leg without strong seta at lower base of first tarsomere ..... 7

7. Wing with vein subcostal smooth (Fig. 13). Vein $\mathrm{A}_{1}+\mathrm{CuA}$ short and strong; vein $\mathrm{A}_{2}$ long and in shape of sigmoid curve (Fig. 13) Fanniidae

Wing with vein subcostal reaching vein costal usually nearly in straight angle (Fig. 12). Vein $\mathrm{A}_{1}+\mathrm{CuA}_{2}$ and vein $\mathrm{A}_{2}$ in different shape not as above (Figs. 12, 14) ........ Muscidae

8. Abdomen and usually thorax with shining metallic blue, green or bronze. Mesonotum sometimes with three dark vittae. Notopleura usually with two setae ... Calliphoridae

Abdomen and thorax dull gray or brown. Mesonotum with three conspicuous dark vittae on gray background. Notopleura usually with two strong setae and two small ones Sarcophagidae

9. Hind leg with first tarsomere usually swollen (Fig. 15) and shorter than the second Sphaeroceridae

Hind leg with first tarsomere longer than the second ..... 10

10. Vein subcostal incomplete not reaching vein costal and usually fusing with vein $\mathrm{R}_{1}$ distally ......... Drosophilidae

Vein subcostal complete reaching vein costal or just for it freely from vein $\mathrm{R}_{1}$ distally (Fig. 4)

11.Vein costal complete without break (Fig. 4). Head rounded (Fig. 16). Palpus short, vestigial. Abdomen usually elongate and basally constricted (ant-like shape) (Fig. 17) Sepsidae

Vein costal incomplete with one or two breaks. Head not rounded. Palpus normal, not vestigial. Abdomen without basal constriction 12

12.Vibrissa absent. Wing variably shaped; cup cell usually with pointed or extended to posterior apex

Ulidiidae (=Otitidae)

Vibrissa present (Fig. 1). Wing moderately broad, with welldeveloped anal lobe and alula; cup cell never pointed or extended to posterior apex (Fig. 18) Piophilidae

\section{Stratiomyidae}

This reasonably diverse, worldwide, family includes 2651 species in 375 genera, 841 species of which are in the Neotropical region (Amorim et al. 2002). Adults can be recognised by the peculiar venation with a small discal cell (Fig. 2).

Soldier flies larvae are usually found on carrion (Smith 1986). Hermetia Latreille is a primarily American and diverse genus with about 50 species (James 1973). Hermetia illucens (Linnaeus) have been found in human cadavers in Brazil (Carvalho et al. 2000). The large adults can reach $15 \mathrm{~mm}$ in body length. The antenna has a spatulated apical flagellum (Fig. 6) and basal segments of the abdomen are transparent. Larvae can be found in human corpses in final stages of decomposition (Oliveira-Costa 2003).

\section{Phoridae}

This family is found in all biogeographic regions, but still lacks a Neotropical Catalogue. Most adults have a peculiar humpbacked thorax and characteristic venation with strong 

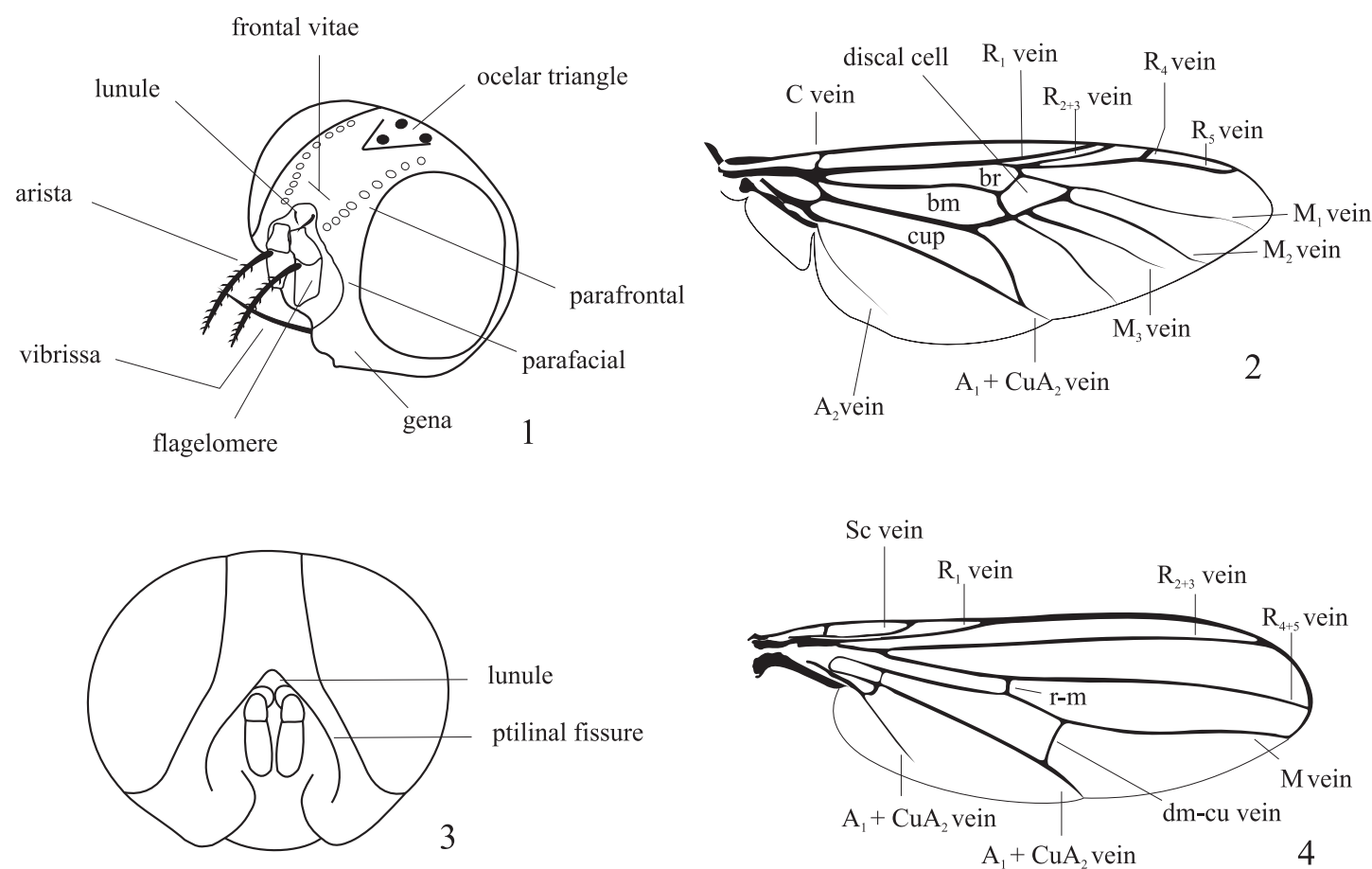

Figs. 1-4. Characters: 1, head, left lateral view; 2, wing, dorsal view, Hermetia illucens (Linnaeus), Stratiomyidae; 3 , head, frontal view, Synthesiomyia nudiseta (Wulp), Muscidae; 4, wing, dorsal view, Sepsidae.

basal and lighter apical veins. Adults are small to medium sized, ranging from 3-5 $\mathrm{mm}$ in body length.

Species of Megaselia Rondani and Puliciphora Dahl have been found in carrion in southern Brazil (Moura et al. 1997) and larvae and adults of Megaselia scalaris (Loew) on human corpses (Carvalho et al. 2000). This species is found in corpses in final stages of decomposition (Greenberg \& Wells 1998), often in cadavers where larger flies have difficult to reach including corpses in cemeteries (Oliveira-Costa 2003).

\section{Anthomyiidae}

Worldwide in distribution, the Anthomyiidae comprise about 1900 species in 54 genera (Thompson 2006), 120 of which are Neotropical (catalogued by Pont 1974). Adults are usually recognised by pale yellow, green or black color. Most species have pale setulae below the scutellum (Fig. 11). A strong seta is found at the base of the first tarsomere on the hind leg. Medium sized flies; they are typically $7-8 \mathrm{~mm}$ in body length and, in general, resemble the common house flies.

Anthomyia punctipennis (Wiedemann) has been found in pig corpses in southern Brazil (Moura et al. 2005).

\section{Fanniidae}

Worldwide in distribution, Fanniidae comprise 285 species in four genera (Carvalho et al. 2003). Commonly named "little house flies," adults may be recognised by the peculiar characteristic wing venation that includes a smooth subcostal vein, and a sigmoidal $\mathrm{A}_{2}$ vein (Fig. 13).

Around 60 Neotropical species are known in the genus Fannia (Albuquerque et al. 1981), and some have been found in carrion in Brazil (Moura et al. 1997). A key to the adults of the most common species in urban or in surrounding areas is available (Carvalho et al. 2002).

Fannia canicularis (Linnaeus) has been collected in pig corpses (Carvalho et al. 2000), larvae of which are illustrated in Queiroz \& Carvalho (1987). Some species may have seasonal distributions, such as F. pusio (Wiedemann) collected in January and F. femoralis (Stein) in February in southern Brazil
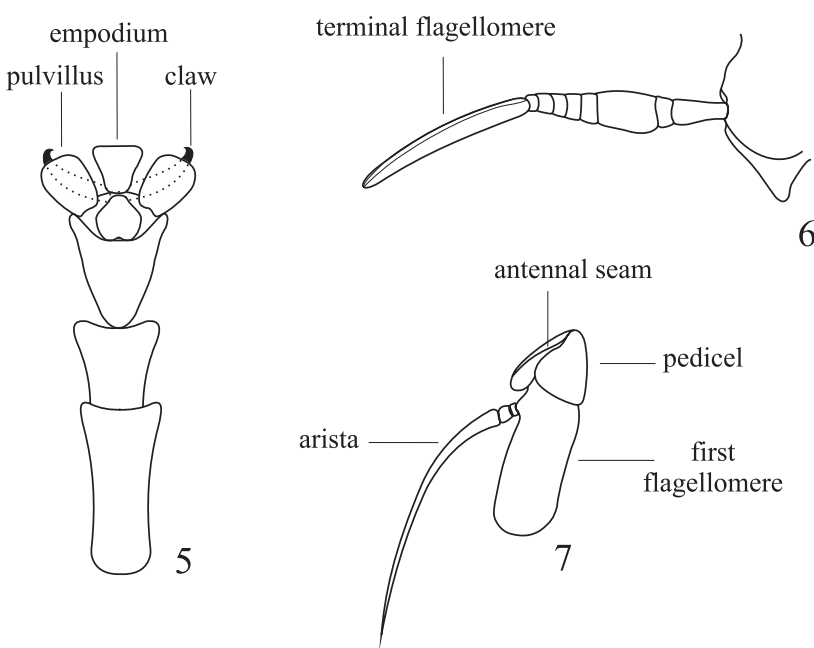

Figs. 5-7. Characters: 5, pulvillus, empodium and claw, Hermetia illucens (Linnaeus), Stratiomyidae; 6, Antenna, terminal flagellomere, Hermetia illucens (Linnaeus), Stratiomyidae; 7, antennal pedicel, Synthesiomyia nudiseta (Wulp), Muscidae. 

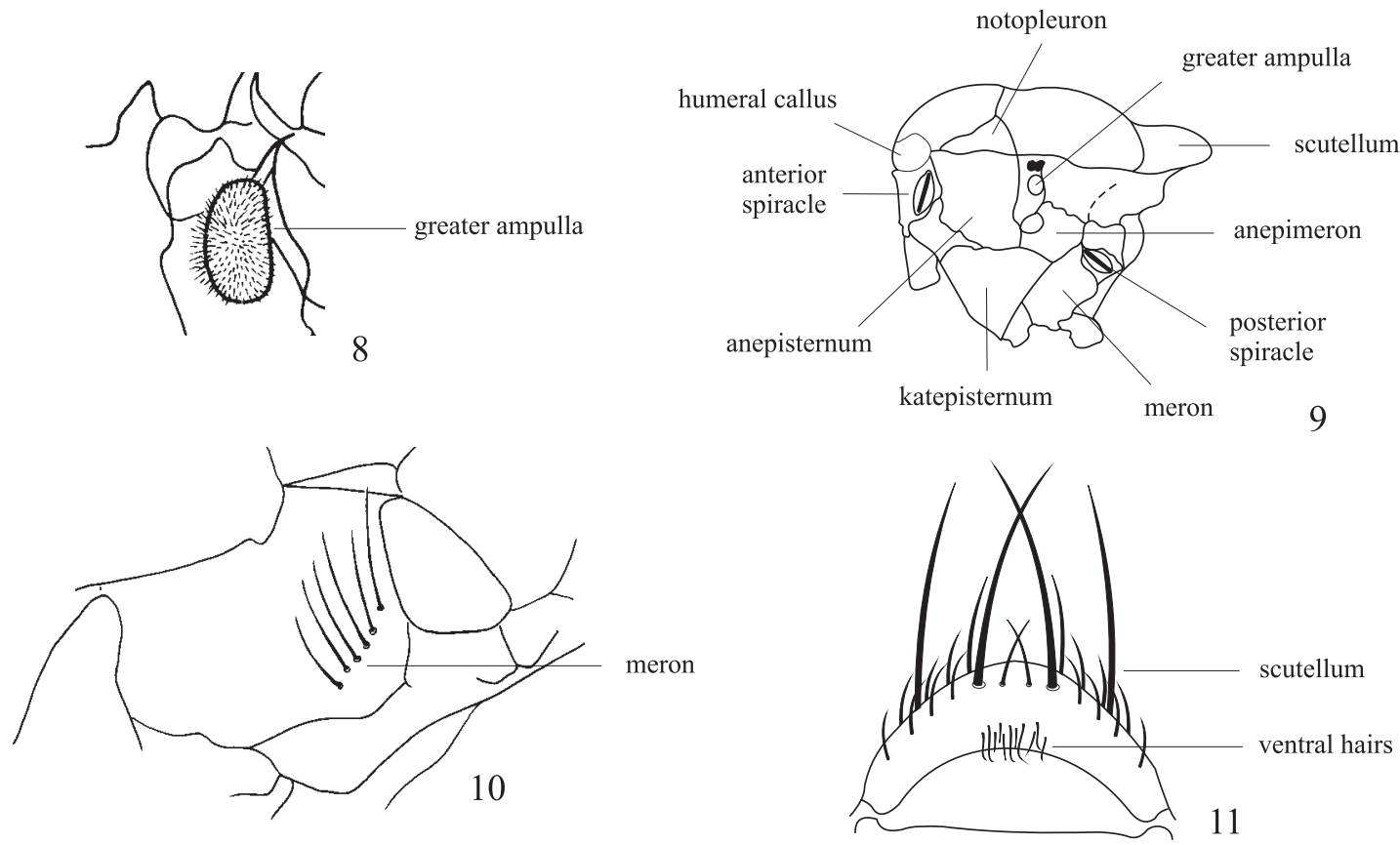

Figs. 8-11. Characters: 8, thorax, greater ampulla, Lucilia eximia (Wiedemann), Calliphoridae; 9, thorax, lateral view, Muscidae; 10, meron with row of setae, Hemilucilia segmentaria, Calliphoridae; 11, scutellum, ventral view, Anthomyiidae.

(Moura et al. 2005). An identification key for adults of the pusio group of Fannia is available (Couri 2005).

Key to South American species of Fanniidae with forensic importance

1. Male: $12-17$ frontal setae (generally up to 13 ). Wing brownish in superior margin. Veins $\mathrm{r}-\mathrm{m}$ and $\mathrm{dm}-\mathrm{cu}$ brownish maculate (slighter in females)

. Fannia obscurinervis (Stein)

Male: fewer than 13 frontal setae (generally fewer than 12). Wing hyaline. Veins $\mathrm{r}-\mathrm{m}$ and $\mathrm{dm}-\mathrm{cu}$ usually without brownish maculate (except $F$. punctipennis Albuquerque)

2. Flies usually 2.5 to $3.5 \mathrm{~mm}$ in body length. Male: $1-2$ and third abdominal tergites trimaculate dorsally (females blackish) [Fannia pusio group] .....

Flies longer than $4 \mathrm{~mm}$ in body length. Male: 1-2 and third abdominal tergites yellow translucent (usually slighter on female)

3. Male: hind femur with 7-8 filiform setulae on middle third of anteroventral surface. Female: parafacialia pollinose to level of tip of pedicel. Parafrontalia shining with a narrow pollinose line around the margin of eye

Fannia trimaculata (Stein)

Male: hind femur without filiform setulae on middle third of anteroventral surface. Female: parafacialia and parafrontalia pollinose but with another pattern ... 4
4. Male: hind tibia with long setae on ventral surface. Female: pollinose on parafrontalia stronger around the margin of eye ...... Fannia pusio (Wiedemann)

Male: hind tibia without setae on ventral surface. Female: pollinose on parafrontalia with uniform pattern

Fannia femoralis (Stein)

5. Hind femur with long setae preapical on posteroventral and ventral surface ........ Fannia punctipennis Albuquerque

Hind femur without long setae preapical on posteroventral and ventral surface ....... Fannia canicularis (Linnaeus)

Muscidae

Houseflies, the Muscidae, occur in all biogeographical regions and comprises around 5,000 species (Thompson 2006). In the Neotropical region 850 species are recognised (Carvalho et al. 2005). They are known as house flies because of Musca domestica Linnaeus, the most famous housefly. Surprisingly, most species in this family are virtually unknown to man (Carvalho \& Couri 2002). Muscidae is a monophyletic group and its members are recognised by chaetotaxy of adult (i.e. bare meron, Fig. 9) and wing characters (Figs. 12, 14). Larvae have a great variety of habits (Skidmore 1985).

A key to all the genera and most species in the Neotropical region is available (Carvalho \& Couri 2002, Couri \& Carvalho 2002). Species in several genera visit carrion and so may be important in forensic studies. Adults of the most common, human associated, Brazilian species were keyed by Carvalho et al. (2002). A key to the larvae of some species is found in Queiroz \& Carvalho (1987). 

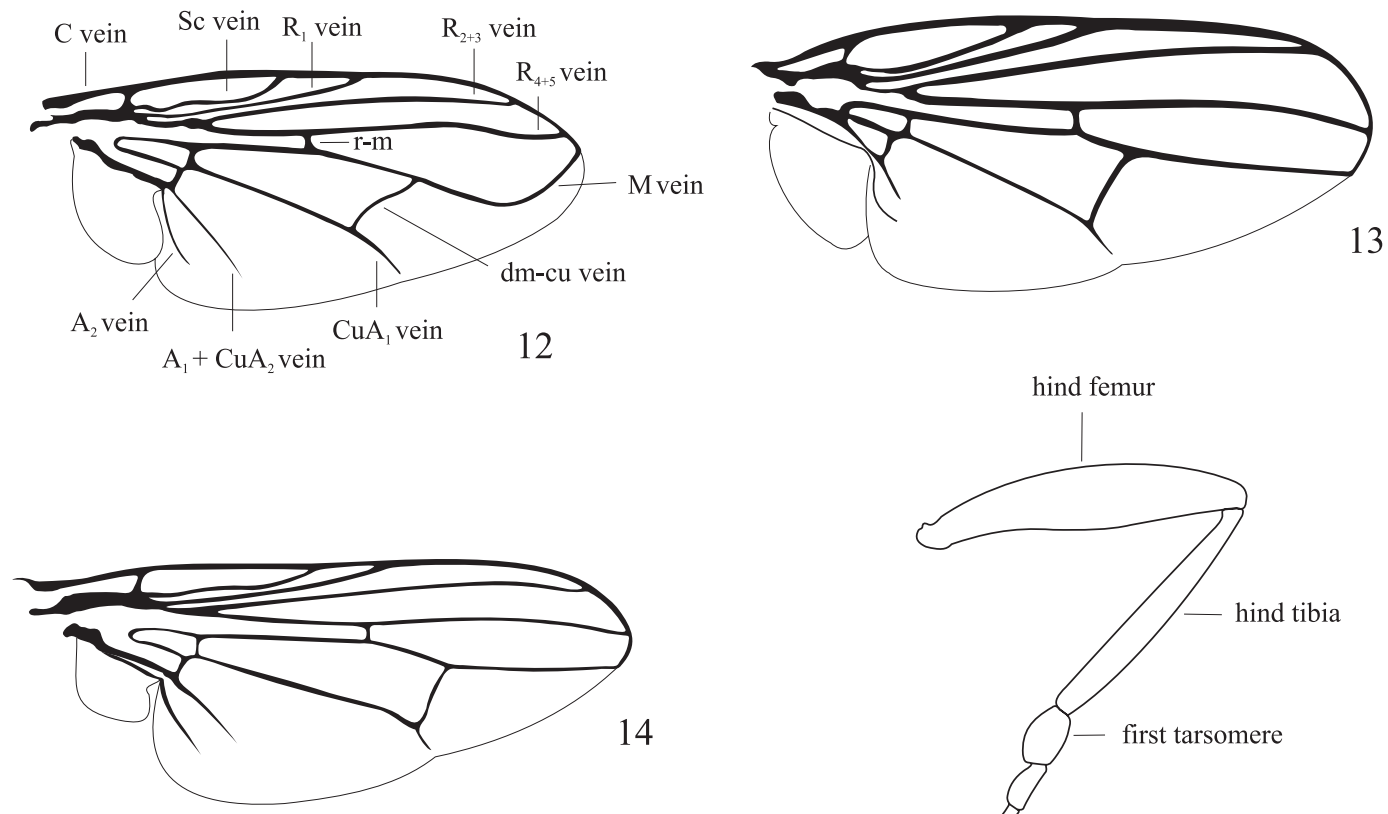

14

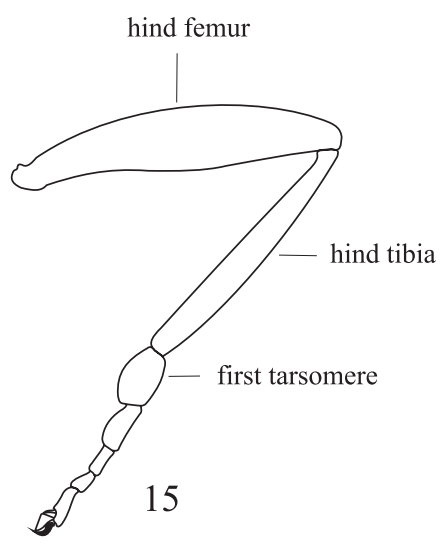

Figs. 12-15. Characters: 12, wing, dorsal view, Synthesiomyia nudiseta (Wulp), Muscidae; 13, wing, dorsal view, Fannia pusio (Wiedemann), Fanniidae; 14, wing, dorsal view, Ophyra aenescens (Wiedemann), Muscidae; 15, hind leg, lateral view, Sphaeroceridae. Costal breaks not indicated.

Oliveira-Costa (2003) summarized the main species and genera of Muscidae associated with carrion or cadavers. The following key is based on that list, along with the species in Moura et al. (1997, 2005).

Key to South American species of Muscidae with forensic importance

1. Head angular in profile. Antenna long reaching to epistome. Antennal insertion above mid-level of eye. Dorsocentral presutural setae very short and fine, almost indistinct from the covering setulae

Atherigona orientalis Schiner

Head shape not as above. Antenna normal not reaching to epistome. Antennal insertion below mid-level of eye. Dorsocentral presutural setae developed or at least differentiated from the covering setulae 2
2. Lower calypter enlarged, sub truncate posteriorly and with the anteromedian angle extending below base of scutellum

Lower calypter glossiform, at most a little enlarged, not extending below base of scutellum 6

3. Supra-squamal ridge setulose. Katepisternal setae 1:3. Apex of abdominal tergite 5 gold yellow

Sarcopromusca pruna (Shannon \& Del Ponte)

Supra-squamal ridge bare. Katepisternum (Fig. 9) with different number of setae. Apex of abdominal tergite 5 not gold yellow 4

4. Katepisternal setae 0:1 or 0:2 (the anterior weak). Male: anterointernal ommatidia very enlarged, with about the same diameter as anterior ocellus

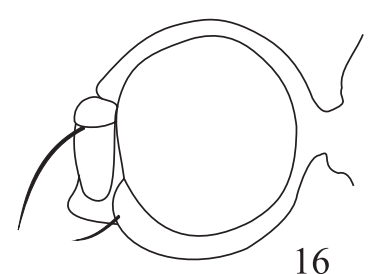

16

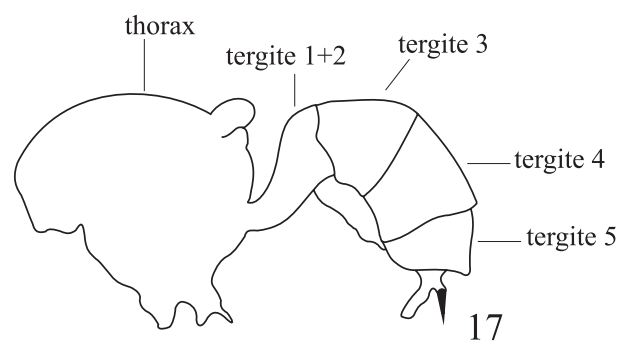

17

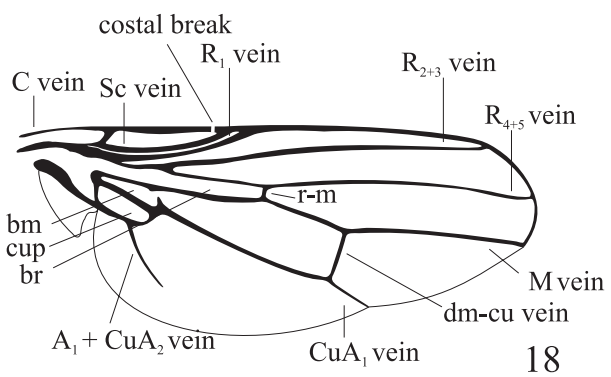

18

Figs. 16-18. Characters: 16, head, lateral view, Sepsidae; 17, thorax and abdomen, lateral view, Sepsidae; 18, wing, dorsal view, Piophila casei (Linnaeus), Piophilidae. 

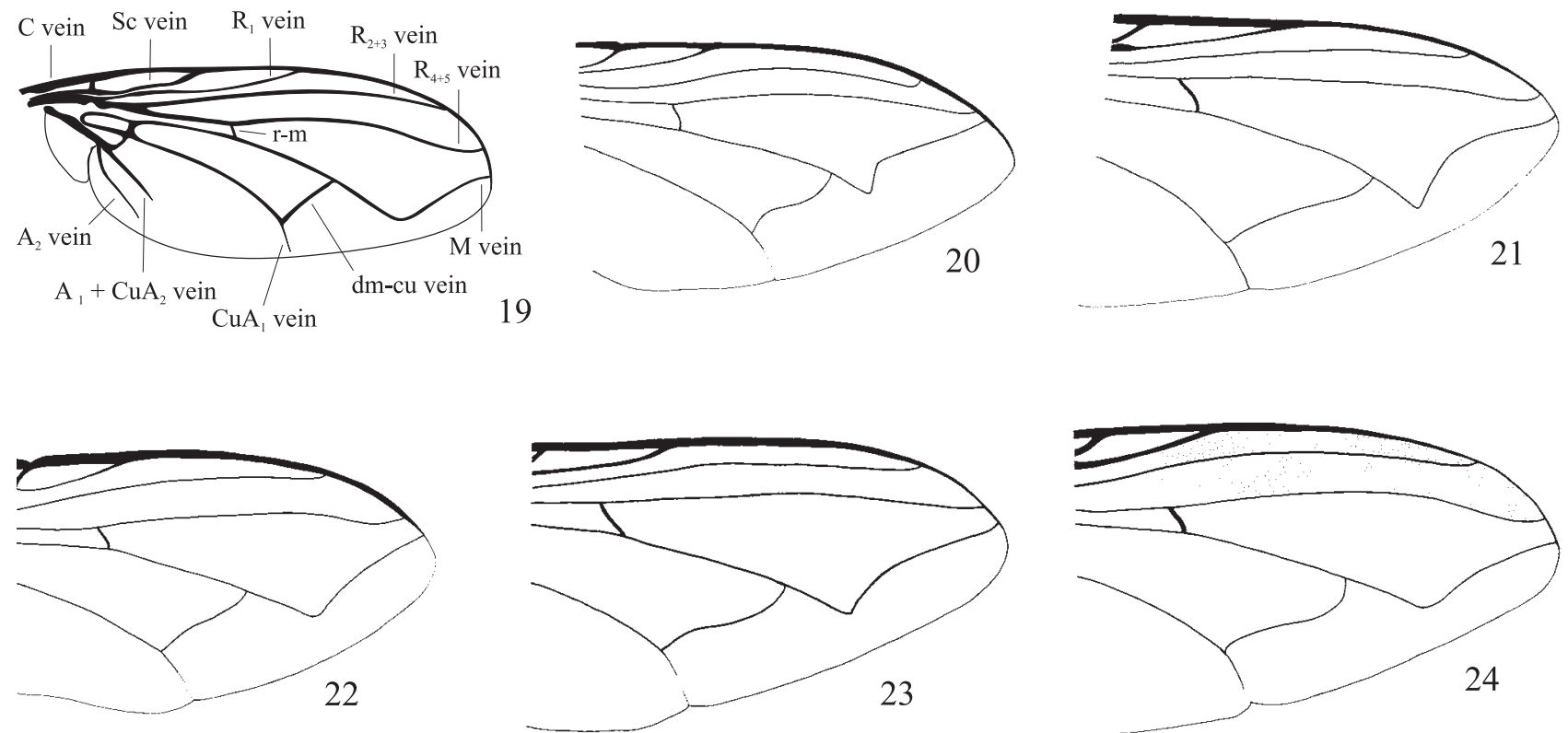

Figs. 19-24. Wing, dorsal view, Calliphoridae: 19, Mesembrinella bellardiana (Aldrich); 20, Sarconesia chlorogaster (Wiedemann); 21, Chrysomya albiceps (Wiedemann); 22, Chrysomya megacephala (Fabricius); 23, Cochliomyia macellaria (Fabricius); 24, Chloroprocta idioidea (RobineauDesvoidy). Costal breaks not indicated.

Biopyrellia bipuncta (Wiedemann)

Katepisternal setae 1:1 or 1:2. Male: anterointernal ommatidia not enlarged as described above ..... .. 5

5. Body metallic blue or green. Acrostichal setae $0: 1$. Metepimeron setulose above hind coxa. Humeral callus (Fig. 9) with 3-4 setae Morellia spp.

Body not metallic blue or green. Acrostichal setae with a different pattern. Metepimeron bare above hind coxa. Humeral callus with $2-3$ setae

Musca domestica Linnaeus

6. Anepimeron ciliated (few to many setulae) 7

Anepimeron (Fig. 9) bare 9

7. Vein $\mathrm{M}$ strongly curved apically. $\mathrm{R}_{4+5}$ ending before wing apex. Apical portion of stem vein with setulae on ventral surface. Vein $\mathrm{R}_{1}$ bare on both surfaces

Neomuscina spp.

Apical section of vein M only slightly bent forward. Apical portion of stem vein bare on ventral surface. Vein $R_{1}$ usually setulose

8. Wing with vein $\mathrm{R}_{1}$ setulose on ventral surface Cyrtoneuropsis maculipennis (Macquart) Wing with vein $\mathrm{R}_{1}$ bare on ventral surface

Cyrtoneurina spp.

9. Wing with vein subcostal meeting the vein costal along its basal third (Fig. 14). Female: proclinate orbital seta present
Wing with vein subcostal meeting vein costal along its distal third or beyond (Fig. 12). Female: proclinate orbital seta absent

10. Gena with a distinct, upward curved seta. General coloration not as above. Female: fronto-orbital seta strong, longer than frontal seta. Ocellar triangle short .. Hydrotaea nicholsoni Curran

Gena with no differentiated setae. Body generally metallic black. Female: fronto-orbital seta weak, shorter than frontal setae. Ocellar triangle usually long, almost reaching to lunule [Ophyra spp.]

11. Male

Female 14

12. Palpus yellow. Hind trochanter, on ventral surface, with tuft of fine, hooked setae

Ophyra aenescens (Wiedemann)

Palpus dark brown or black. Hind trochanter, on ventral surface, without tuft of fine setae ..... 13

13. Fore tarsomeres not yellow on ventral surface. Mid femur, on basal half of ventral surface, with a row of 10-12 strong setae. Calypters infuscated with dark brown margins Ophyra albuquerquei Lopes

Fore tarsomeres yellow on ventral surface. Mid femur, on basal half of ventral surface, with a row of 4-6 fine cilia. Calypters hyaline ... Ophyra chalcogaster (Wiedemann)

14. Ocellar triangle shorter, not reaching lunule or not ending 

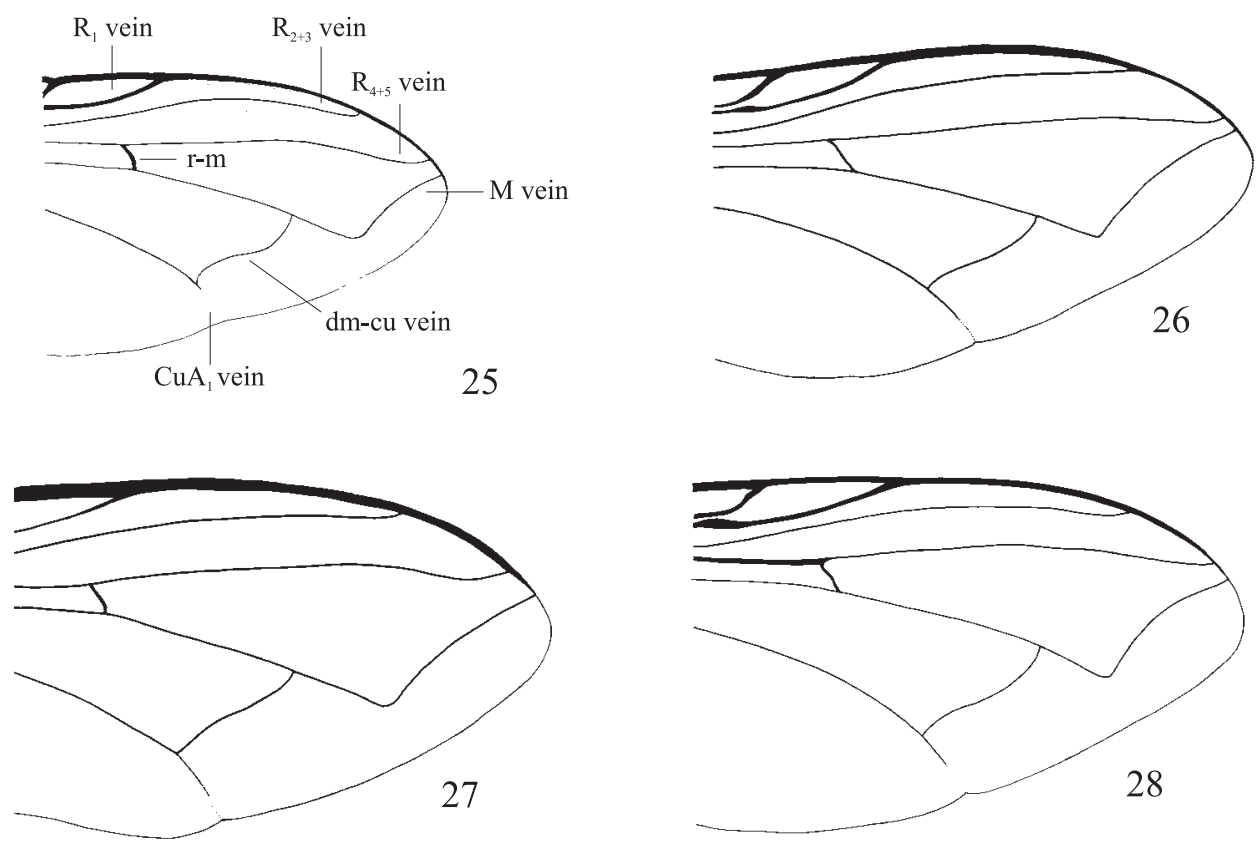

Figs. 25-28. Wing, dorsal view, Calliphoridae: 25, Hemilucilia segmentaria (Fabricius); 26, Lucilia cuprina (Wiedemann); 27, Lucilia eximia (Wiedemann); 28, Lucilia sericata (Meigen).

close to it. Fore tarsomeres usually yellowish on ventral surface (not so evident as in male)

Ophyra chalcogaster (Wiedemann)

Ocellar triangle long, reaching lunule or ending very close to it. Fore tarsomeres not yellowish on ventral surface 15

15. Palpus yellow Ophyra aenescens (Wiedemann) Palpus dark brown to black .... Ophyra albuquerquei Lopes

16. Wing with Rs (radial sector) node or base of vein $R_{4+5}$ usually with one cilium on dorsal surface. Only two katepisternal posterior setae, the anterior seta absent Graphomya spp.

Wing with Rs node or base of vein $\mathrm{R}_{4+5}$ without cilia on dorsal surface. Three katepisternal setae, the anterior seta present

17. Labella reduced. Prestomal teeth developed. Postsutural dorsocentral setae 2 .. Bithoracochaeta calopus (Bigot)

Labella not reduced. Prestomal teeth not developed. Postsutural dorsocentral seta 3-4 .18

18. Body metallic blue. Apical section of vein $\mathrm{M}$ straight forward Psilochaeta pampiana (Shannon \& Del Ponte)

Body not metallic blue. Apical section of vein M strongly curved forward (Fig. 12) Synthesiomyia nudiseta (Wulp)

Calliphoridae

Blow flies occur in all biogeographic regions and comprise around 1500 species (Thompson 2006). In the Neotropical region about 130 species are known, but the taxonomy of the family is still being studied and several new species are probably to be discovered, especially in the Andes. Some genera, such Paralucilia Brauer \& Bergenstamm need revision. Adults are identified by their chaetotaxy (setae on meron, Fig. 10) and by wing characters (Figs. 19-29, 31, 34). They are medium to large flies (4-16 mm in length). Most species are probably of medical or hygienic importance, since adults can carry pathogens to human or domestic food. Some species lay eggs in fresh skin lesions and the larvae burrow in healthy tissues (Mello 2003). Larvae of most species are necrophagous, and females oviposit in all kinds of carcasses, including human, while few species, e.g. Chrysomya albiceps (Wiedemann) are predators at carcasses. Also, this species may be a secondary myiasis fly in animals (Baumgartner \& Greenberg 1985; Guimarães \& Papavero 1999).

Several key to adults have been published in South America during the last 25 years, usually restricted to a country or region (Brazil: Ribeiro \& Carvalho 1998; Carvalho \& Ribeiro 2000; Mello 2003; Argentina: Mariluis 1982) or to a single subfamily (Dear 1985). Larvae of some Calliphoridae species were illustrated and keyed (Greenberg \& Szyska 1984; Queiroz \& Carvalho 1987).

Oliveira-Costa (2003) summarized the most common species of Calliphoridae associated with carrion or cadavers. Some species have been used for many years to estimate the time of death. Chrysomya albiceps, C. megacephala (Fabricius), C. putoria (Wiedemann) arrived in South America about 30 years ago, and have since had importance in some urban areas where were found in carrion or corpses (Monteiro- 

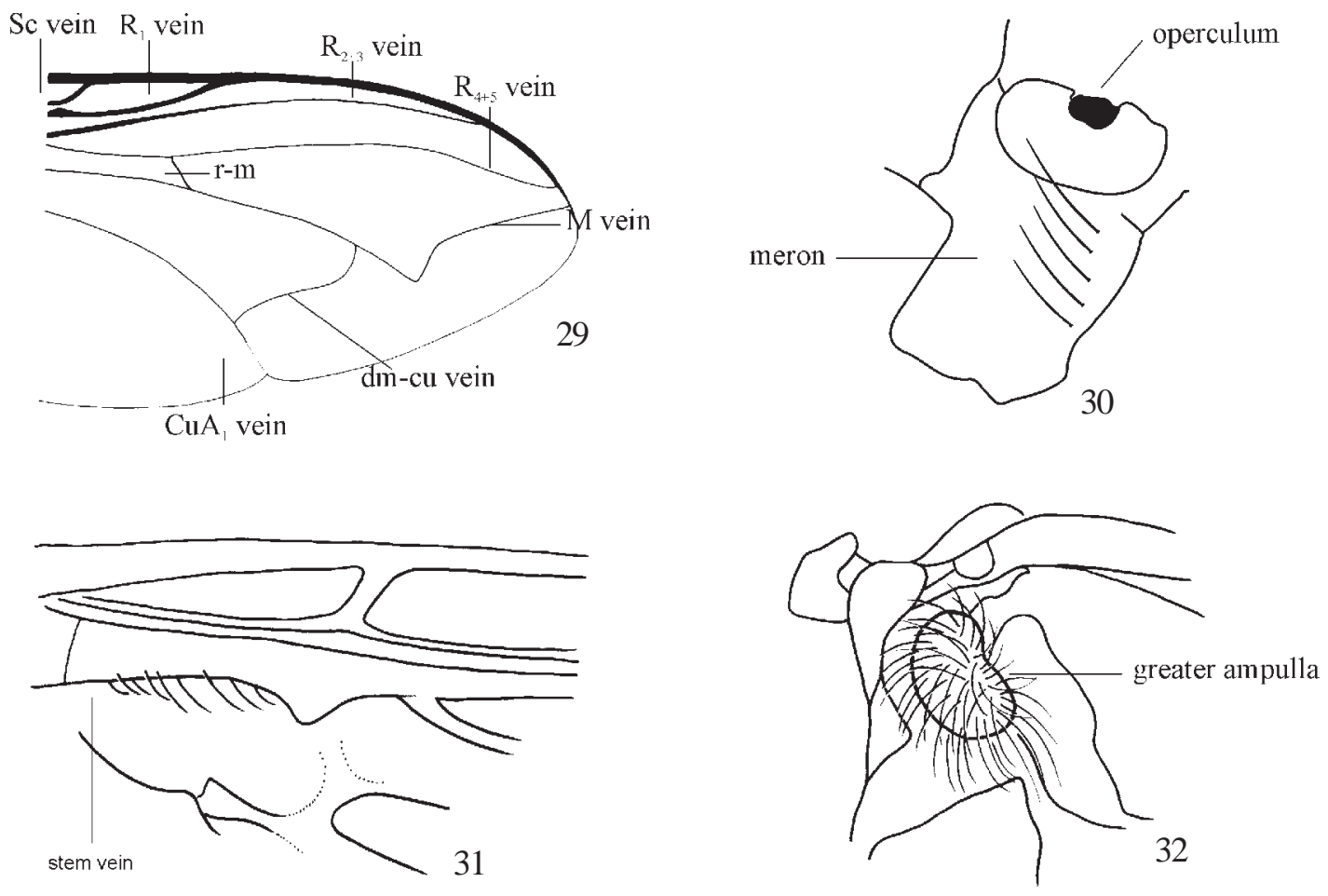

Figs. 29-32. Characters: 29, wing, dorsal view, Calliphora vicina Robineau-Desvoidy, Calliphoridae; 30, thorax, posterior spiracle, Mesembrinella bellardiana (Aldrich); 31, wing, basal section of stem vein, dorsal view, Chloroprocta idioidea (Robineau-Desvoidy); 32, thorax, greater ampulla, Chrysomya albiceps (Wiedemann).

Filho \& Penereiro 1987; Souza \& Linhares 1997; Moura et al. 1997; Carvalho et al. 2000; Oliva 2001). Two species of Chrysomya Robineau-Desvoidy were found on human cadavers in Cali, Colombia: C. megacephala and C. rufifacies (Macquart) (Barreto et al. 2002). Chrysomya albiceps is frequently confused with C. rufifacies in South America. Wells \& Sperling (1999) described the molecular phylogeny of those two species.

Other species, e.g. Lucilia eximia (Wiedemann), Cochliomyia macellaria (Fabricius), Hemilucilia segmentaria (Fabricius), H. semidiaphana (Rondani), Paralucilia fulvinota (Bigot) and Sarconesia chlorogaster (Wiedemann) have been recognized as the most important for forensics in South America (Monteiro-Filho \& Penereiro 1987; Salviano et al. 1996; Souza \& Linhares 1997; Moura et al. 1997, 2005; Carvalho et al. 2000; Oliva 2001; Pujol-Luz et al. 2006). In Peru species of Sarconesia and Compsomyiops Townsend were found in human corpses (Marco Villacorta, personal communication).

An identification key follows, based on species indicated by Oliveira-Costa (2003) with the addition of the above species, to describe the forensically most important species.

Key to South American species of Calliphoridae with forensic importance

1. Wing with vein M strongly curved (Fig. 19). Posterior spiracle with one operculum (Fig. 30) (Mesembrinellinae)
Mesembrinella bellardiana (Aldrich)

Wing with vein M distinctly curved (Fig. 20). Posterior spiracle with two opercula

2. Wing with basal section of stem vein $(\mathrm{R})$ on dorsal view with setulae (Fig. 31). Greater ampulla reniform (Fig. 32) (Chrysomyinae)

Wing with basal section of stem vein $(\mathrm{R})$ on dorsal view without setulae. Greater ampulla oval (Fig. 8) (Calliphorinae).

3. Arista bare on distal end (Fig. 33). Basal section of stem vein (R) on ventral view with setulae (Fig. 34). Thorax not metallic (Toxotarsini)

Sarconesia chlorogaster (Wiedemann)

Arista pilose on distal end (Fig. 35). Basal section of stem vein $(\mathrm{R})$ on ventral view bare. Thorax metallic (Chrysomyini)

4. Mesonotum without conspicuous vittae. Wholly upper calypter on dorsal view with hairs (Fig. 36). Greater ampulla with long hairs (Fig. 32) (Chrysomya) ............. 5

Mesonotum with conspicuous vittae (Fig. 37). Upper calypter bare or at most with hairs only on basal half. Greater ampulla only pilose 7

5. Anterior spiracle brownish. Male: eye with only superior 

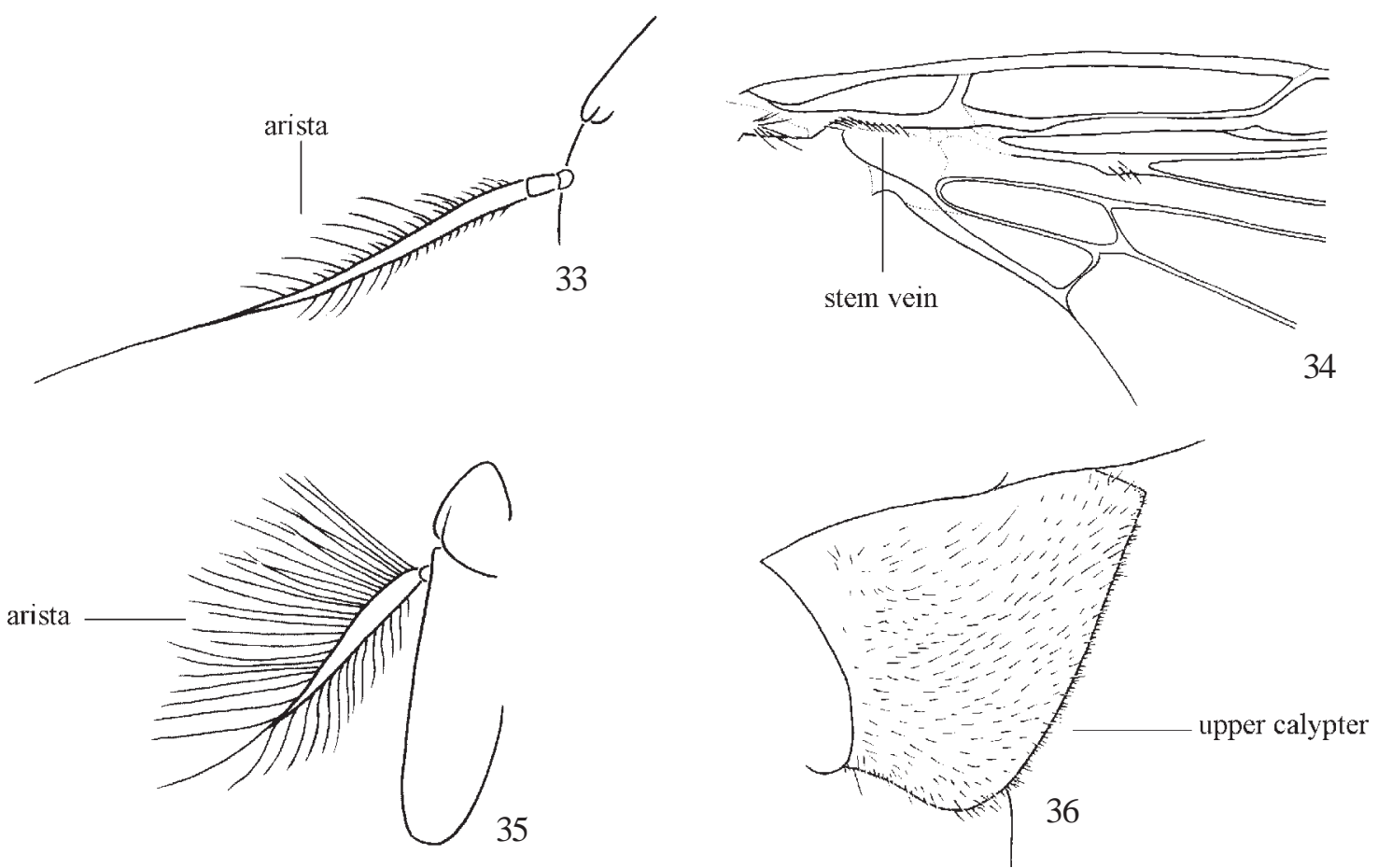

Figs. 33-36. Characters: 33, arista, Sarconesia chlorogaster (Wiedemann); 34, wing, basal section of stem view, ventral view, Sarconesia chlorogaster (Wiedemann); 35, arista, Chrysomya albiceps (Wiedemann); 36, upper calypter, dorsal view, Chrysomya albiceps (Wiedemann). Costal breaks not indicated.

ommatidia large ... Chrysomya megacephala (Fabricius) Anterior spiracle whitish. Male: eye with normal ommatidia 6

6. Proepimeral seta present (below anterior spiracle) (Fig. 38) Chrysomya putoria (Wiedemann)

Proepimeral seta absent

Chrysomya albiceps (Wiedemann)

7. Inferior calypter with setulae on basal third or internal half of dorsal surface ...8

Inferior calypter totally bare on dorsal surface 11

8. Palpus short, filiform (Fig. 39) Cochliomyia macellaria (Fabricius)

Palpus normal, club shape

9. Legs mostly reddish. Presutural dorsocentral setae absent. Inferior calypter with setulae on basal third of dorsal surface

Compsomyiops fulvicrura (Robineau-Desvoidy)

Legs mostly blackish. Presutural dorsocentral setae present. Inferior calypter with setulae on internal half of dorsal surface .. 10

10. Male: $7-8$ weak frontal setae. Female: $9-11$ frontals setae . Paralucilia fulvinota (Bigot)

Male: 10-12 frontal setae, the upper ones weak. Female: 10-12 frontal setae and 1 strong pair out curved ocellar setae Paralucilia xanthogeneiates (Dear)
11. Legs blackish. Wing with maculae restricted to costal margin

Chloroprocta idioidea (Robineau-Desvoidy)

Legs yellowish. Wing with faint maculae in distal third, but strong near vein costal 12

12. Thorax with pleural sclerites totally green or blue. Posterior spiracle black or dark brown in colour. Superior calypter with setulae on dorsal surface in male and female . Hemilucilia semidiaphana (Rondani)

Thorax with pleural sclerites yellowish. Posterior spiracle yellowish in colour. Superior calypter bare in male and with setulae in female on dorsal surface

Hemilucilia segmentaria (Fabricius)

13. Inferior calypter bare on dorsal surface. Parafacialia usually entirely bare 14

Inferior calypter with setulae on dorsal surface. Parafacialia partially with setulae. 16

14. Two acrostichals postsutural setulae

Lucilia eximia (Wiedemann)

Three acrostichals postsutural setulae 15

15. Body with copper coloration. Thorax with $2-4$ humeral setae Lucilia cuprina (Wiedemann)

Body with metallic green or blue coloration. Thorax with 6-8 humeral setae Lucilia sericata (Meigen)

16. Gena reddish. Anterior spiracle yellow. Basicosta yellowish 

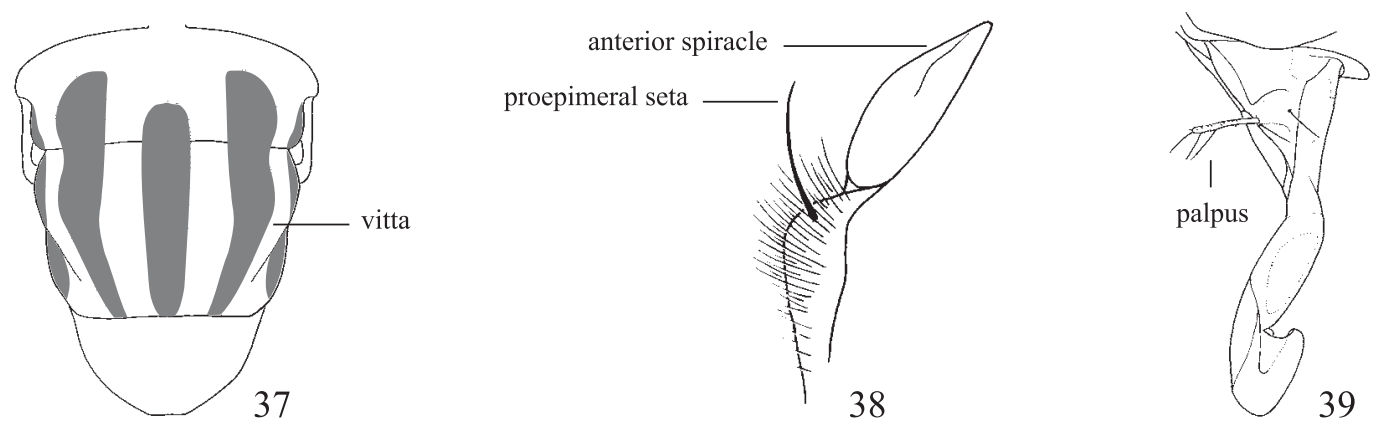

Figs. 37-39. Characters: 37, mesonotum, Cochliomyia macellaria (Fabricius); 38, thorax, proepimeral setae, Chrysomya putoria (Wiedemann); 39 , proboscis and palpus, lateral view, Cochliomyia macellaria (Fabricius).

Calliphora vicina Robineau-Desvoidy

Gena totally black. Anterior spiracle dark brown. Basicosta black Calliphora lopesi (Mello)

Sarcophagidae

The flesh flies are saprophagous and of great importance for the decomposition of animal matter. Thus, they are of forensic importance, especially since they prefer advanced stages of decomposition (Carvalho \& Linhares 2001). Species of this family are always found in succession studies and while not as abundant as the Calliphoridae and Muscidae, they are often the most diverse on pig or human carcasses (Oliveira-Costa et al. 2001). Some species are attracted by excrement and others have caused myiasis in man and domestic animals (Guimarães \& Papavero 1999). Incubation to hatching of the eggs is intrauterine and females deposit first instar larvae, whose cephalopharyngeal skeleton is always strongly sclerotized (Lopes 1943, 1982, Shewell 1987).

About 2500 species comprise this worldwide family, in which the Neotropical fauna is most diverse, with more than 800 species (Pape 1996). There are three subfamilies, Miltogrammatinae, Paramacronychiinae and Sarcophaginae, of which the latter is the most speciose, common in the New
World, and diverse in biology and forensic importance (Pape 1996, Pape et al. 2006).

Most flesh flies are medium to large sized flies (8-14mm), and uniform in general, being dull gray with three longitudinal black strips in the mesonotum and abdomen checkered or spotted, a row of setae in the meron and an undeveloped subscutellum. Some species have a variable golden microtrichosity. Chaetotaxy is also uniform and few external characters can be used safely for the species identification. Therefore, the structure and form of the male terminalia provide characters for identification. No suitable key for identifying Neotropical genera yet exists and the elaboration of one will be very difficult without analysis of the male terminalia. Unfortunately, the lack of specialists in this area, but especially the difficulty for non-specialists to correctly examine and analyze male terminalia, have seriously limited studies of this family.

The key given below provides genus-level identification based on the morphology of adult male of sarcophagid species that were recorded in carrion and on corpses in South America (Jiron et al. 1983; Oliveira-Costa 2003; Moura 2004; Oliveirada-Silva et al., 2006) (included species in brackets [ ], see below). Nomenclature used here follows Pape (1996).
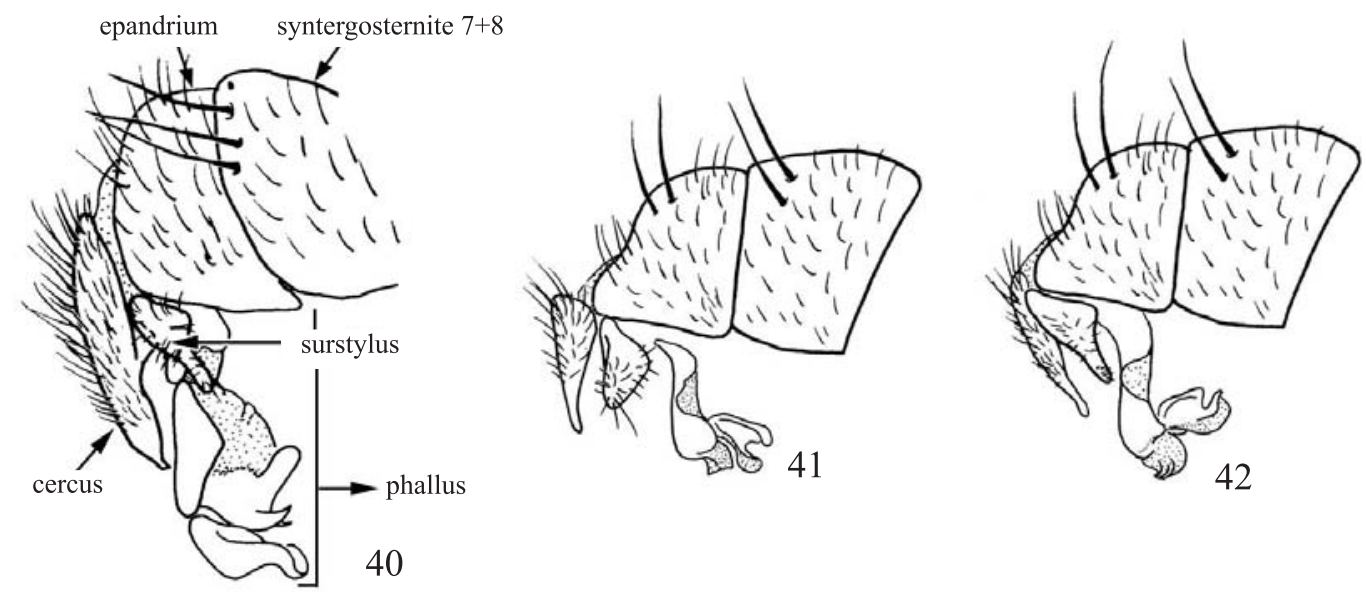

Figs. 40-42. Male terminalia: 40, Microcerella halli (Engel); 41, Tricharaea (Sarcophagula) canuta (Wulp); 42, Tricharaea (Sarcophagula) occidua (Fabricius). 

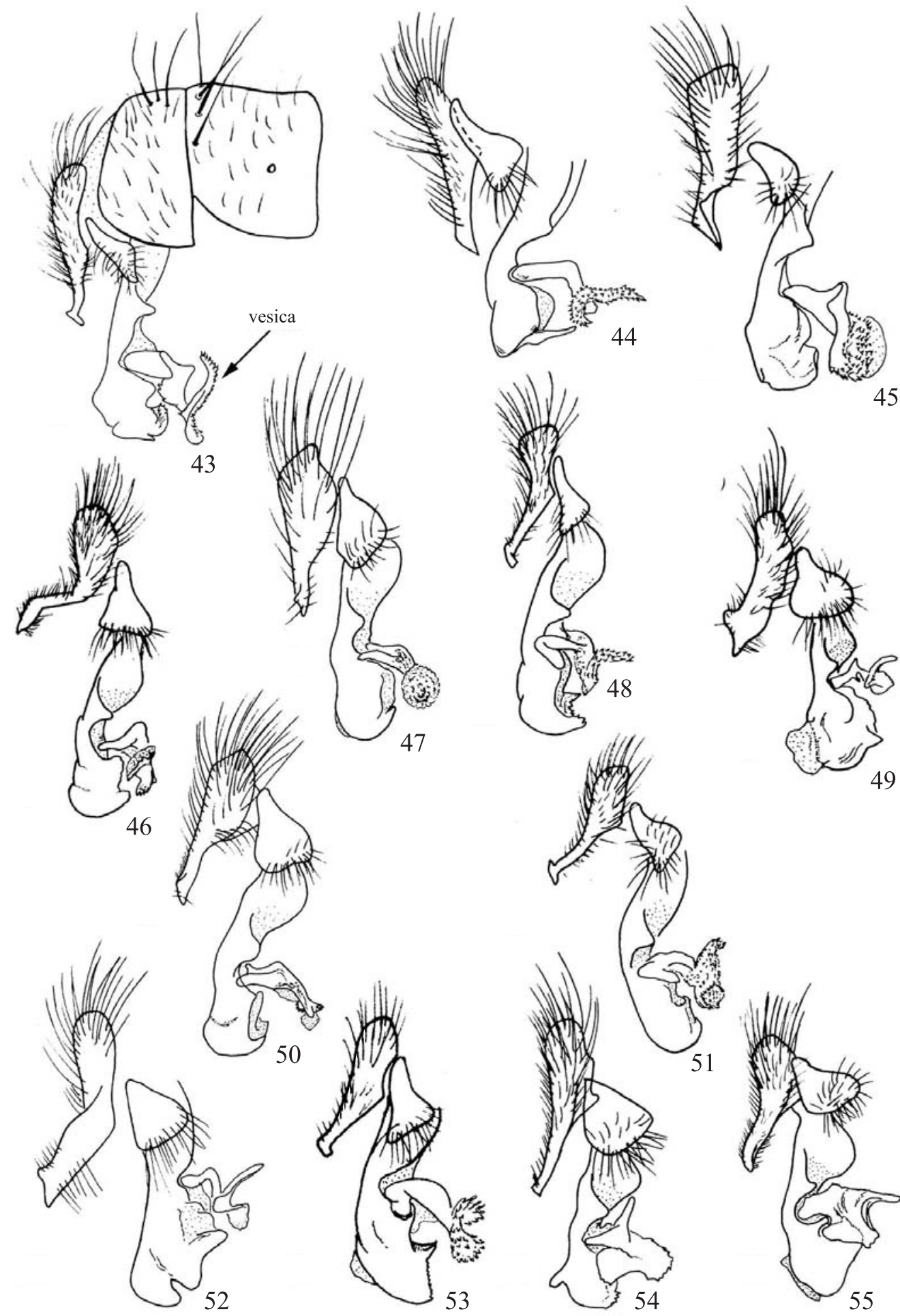

49

Figs. 43-55. Male terminalia of Oxysarcodexia: 43, O. amorosa (Schiner); 44, O. angrensis (Lopes); 45, O. avuncula (Lopes,); 46, O culmiforcipes Dodge; 47, O. diana (Lopes); 48, O. fluminensis Lopes; 49, O. intona (Curran \& Walley); 50, O. parva Lopes; 51, O. paulistanensis (Mattos); 52, O. peltata (Aldrich, 1916); 53, O. riograndensis Lopes; 54, O. thornax (Walker); 55, O. timida (Aldrich).

Key to adult males of South American genera of Sarcophagidae of forensic importance

1. Arista short plumose in less than the basal half of the arista length. Parafacial setae strong but restricted to a small area below of middle of eye. Phallus (Fig. 40) Microcerella [included species: $M$. halli (Engel) (= Townsendmyia halli)] Arista long plumose for more than basal half of arista 

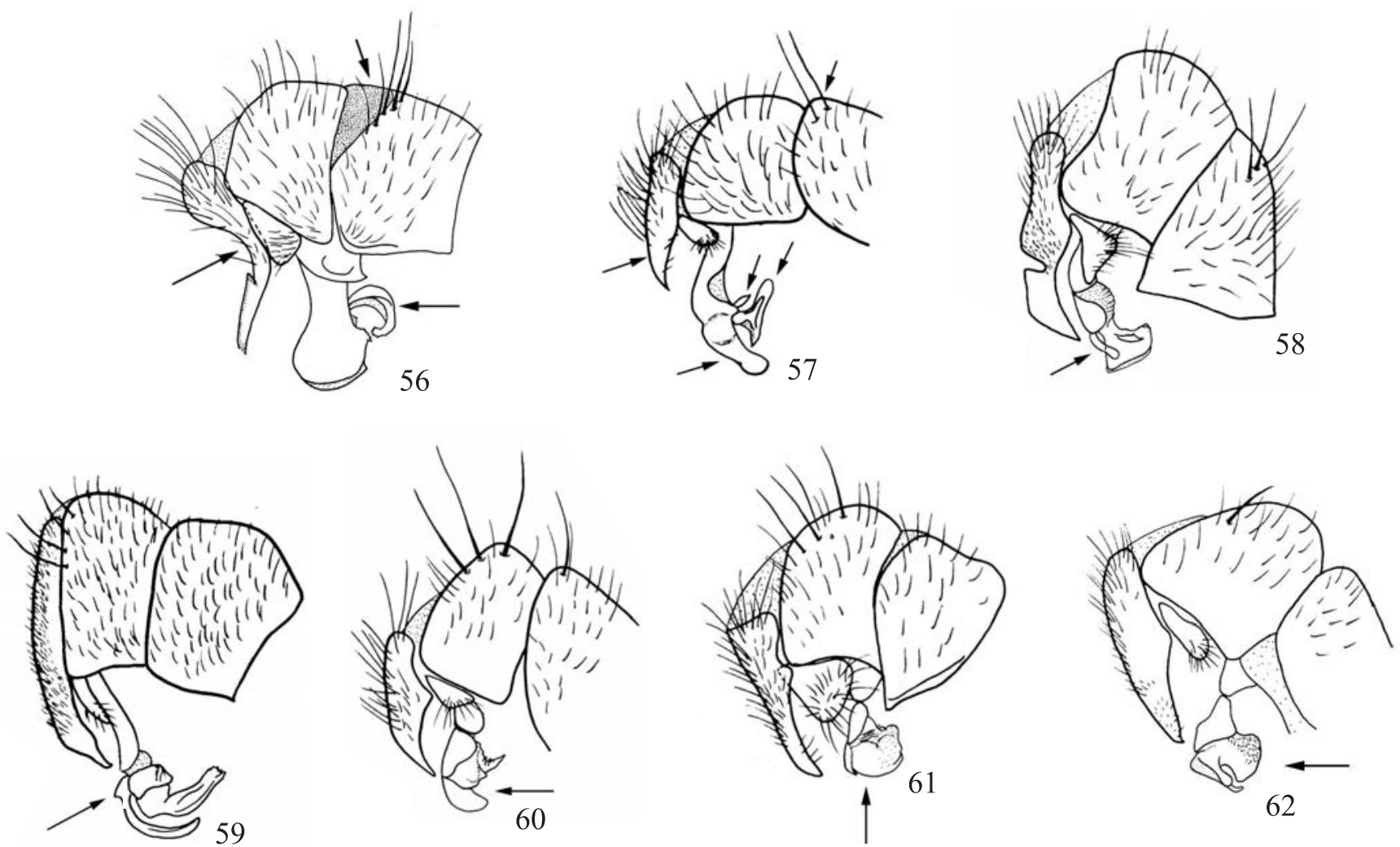

Figs. 56-62. Male terminalia: 56, Oxysarcodexia terminalis (Wiedemann); 57, Ravinia belforti (Prado \& Fonseca); 58, Peckia (Squamatodes) ingens (Walker); 59, Peckia (Squamatodes) trivittata (Curran); 60, Helicobia aurescens (Townsend); 61, Helicobia morionella (Aldrich); 62, Helicobia pilifera Lopes.

length. Parafacial setae not well-developed and mostly in row along of eye margin

2. Male: 1 proclinate fronto-orbital seta. Small specimens, less than $5 \mathrm{~mm}$. Wing vein $\mathrm{R}_{1}$ bare. Mid femur without ctenidium (a comb-like row of modified and spiniform setae on the apex of the posteroventral margin). Phallus (Figs. 41-42)

.. Tricharaea (Sarcophagula) [included species: T. (S.) canuta (Wulp) and T. (S.) occidua (Fabricius)]

Male: without proclinate fronto-orbital setae. Specimens of variable size, at most $5 \mathrm{~mm}$. Wing with vein $\mathrm{R}_{1}$ bare or setose. Mid femur with or without ctenidium . .3

3. Mid femur with ctenidium of flattened spines. Postgena with few whitish setae. Gena with black setae. Phallus entire with only an indication of hinge between basiphallus and distiphallus ..... .... 4

Mid femur without ctenidium or with ctenidium of normal spines (not flattened). Postgena with white setae. Gena with most setae whitish. Phallus with only an indication of hinge or with a distinct articulation between basiphallus and distiphallus .....
4. Wing with tegula dull gray or black (darker than the costal vein). Basicosta yellowish. Phallus with a vesica (=ventralia, a ventral, in general articulated, projection of the distiphallus) conspicuously developed and ornamented. Phallic apex with variable shape (Figs. 43$55)$ Oxysarcodexia (in part) [included species: O. amorosa (Schiner), O. angrensis (Lopes), O. avuncula (Lopes,), O. culmiforcipes Dodge, $O$. diana (Lopes), O. fluminensis Lopes, O. intona (Curran \& Walley), O. parva Lopes, O. paulistanensis (Mattos), O. peltata (Aldrich, 1916), O. riograndensis Lopes, O. thornax (Walker), O. timida (Aldrich)]

Wing with tegula yellowish brown (similar to color of costal vein). Basicosta whitish yellow. Phallus variable ....... 5

5. Phallus with a developed and curved vesica. Phallus apex almost truncated. Cercus concave in median region in lateral view. Syntergosternite $7+8$ with a large posterior dark stripe (Fig. 56)

.. Oxysarcodexia (in part) [included species: O. terminalis (Wiedemann) (= Hybopygia terminalis)] Phallus with a simple vesica without ornaments and a hillae (sensu Roback 1954) below the vesica in lateral view; 

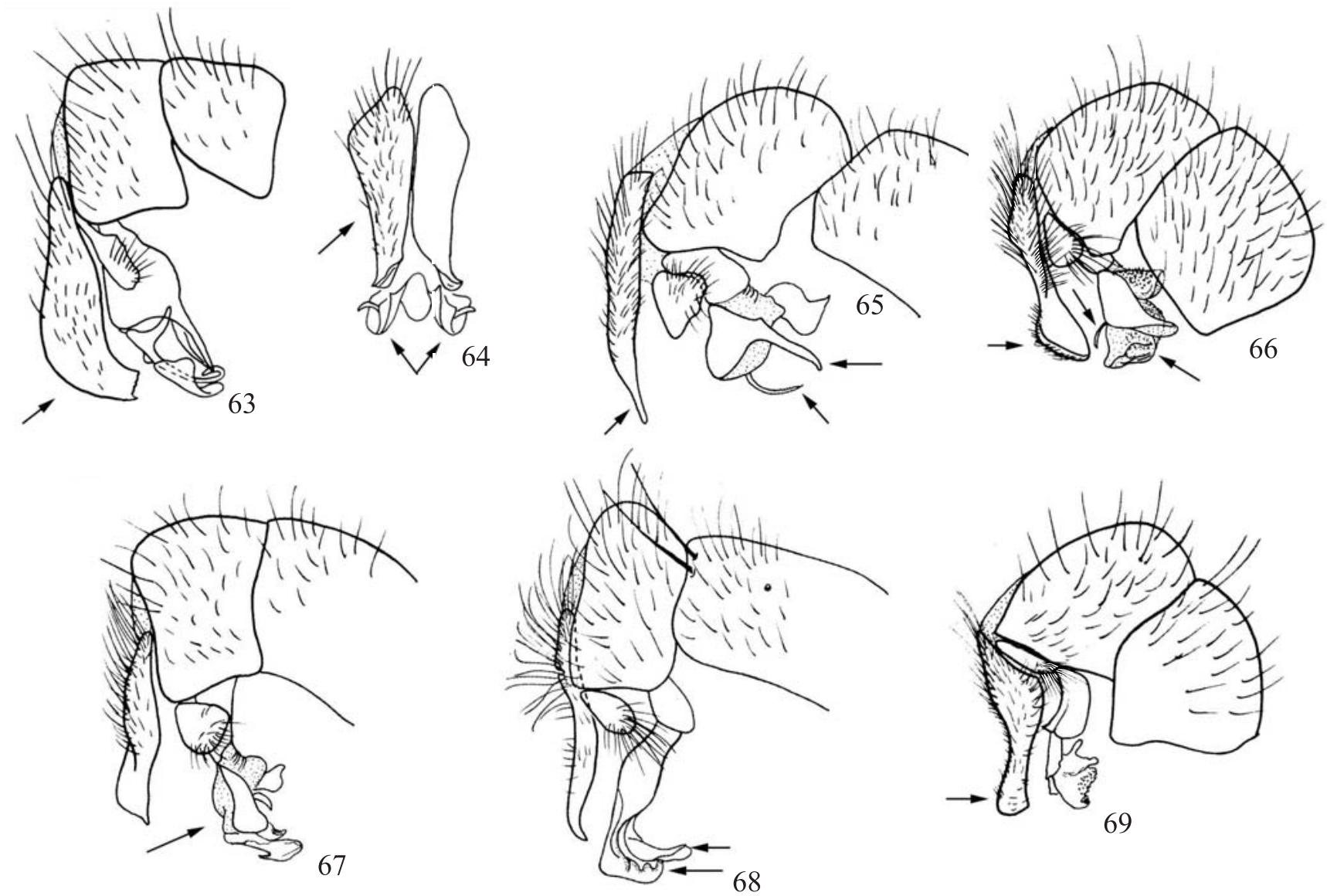

Figs. 63-69. Male terminalia: 63, Sarcodexia lambens (Wiedemann), lateral view; 64, S. lambens (Wiedemann), posterior view; 65, Peckia (Peckia) chrysostoma (Wiedemann); 66, Engelimyia inops (Walker); 67, Sarcophaga (Liopygia) ruficornis (Fabricius); 68, Sarcophaga (Bercaea) africa (Wiedemann); 69, Titanogrypa (Cuculomyia) larvicida (Lopes).

phallus apex rounded and lightly narrow. Cercus straight in lateral view. Syntergosternite $7+8$ without a large posterior dark stripe (Fig. 57) Ravinia [included species: $R$. belforti (Prado \& Fonseca)]

6. Lower calypter with black hairs on dorsal surface. Phallus (Figs. 58-59)

Peckia (Squamatodes) [included species: $P$. (S.) ingens (Walker) and $P$. (S.) trivittata (Curran)]

Lower calypter without dorsal black hairs 7

7. Mid femur without ctenidium, but some robust and hairy species can have an apical row of shorter (but not spiniform) setae on the posterior margin ....

Mid femur with ctenidium of normal spines (not flattened)

8. Small to medium specimens (5-7 mm). Wing with vein $R_{1}$ setose and third costal sector bare ventrally. Postalar wall setose. Parafacial plate with strong setae. Phallus small and with a simple distiphallus (Figs. 60-62) Helicobia [included species: $H$. aurescens (Townsend), $H$. morionella (Aldrich), $H$. pilifera Lopes]

Medium to robust specimens. Wing vein $\mathrm{R}_{1}$ bare. Other characters variable

9. Phallus with a bifid apex due to a dorsal plate split apically into two dorsolateral prongs with an apical finger-like extension (Figs. 63-64). Cerci shell-like, bent forward, and with divergent apex in posterior view. Mid tibia with long median anterior setae that reach and surpass the tibial apex .....

Sarcodexia [included species: S. lambens (Wiedemann) $(=$ S. innota $($ Walker $)=S$. sternodontis Townsend ]

Phallus not as above. Cerci nearly straight or lightly bent forward. Mid tibia with median posterior setae of the not as long as tibia apex .....

10. Robust and hairy specimens. Cercus distally acute. Phallus with a conspicuous ventral projection and with long and filiform lateral styli projected out of the phallic apex (Fig. 65) Peckia (Peckia) [included species: P. (P.) chrysostoma (Wiedemann)] Median to robust specimens. Cercus distally widened. 

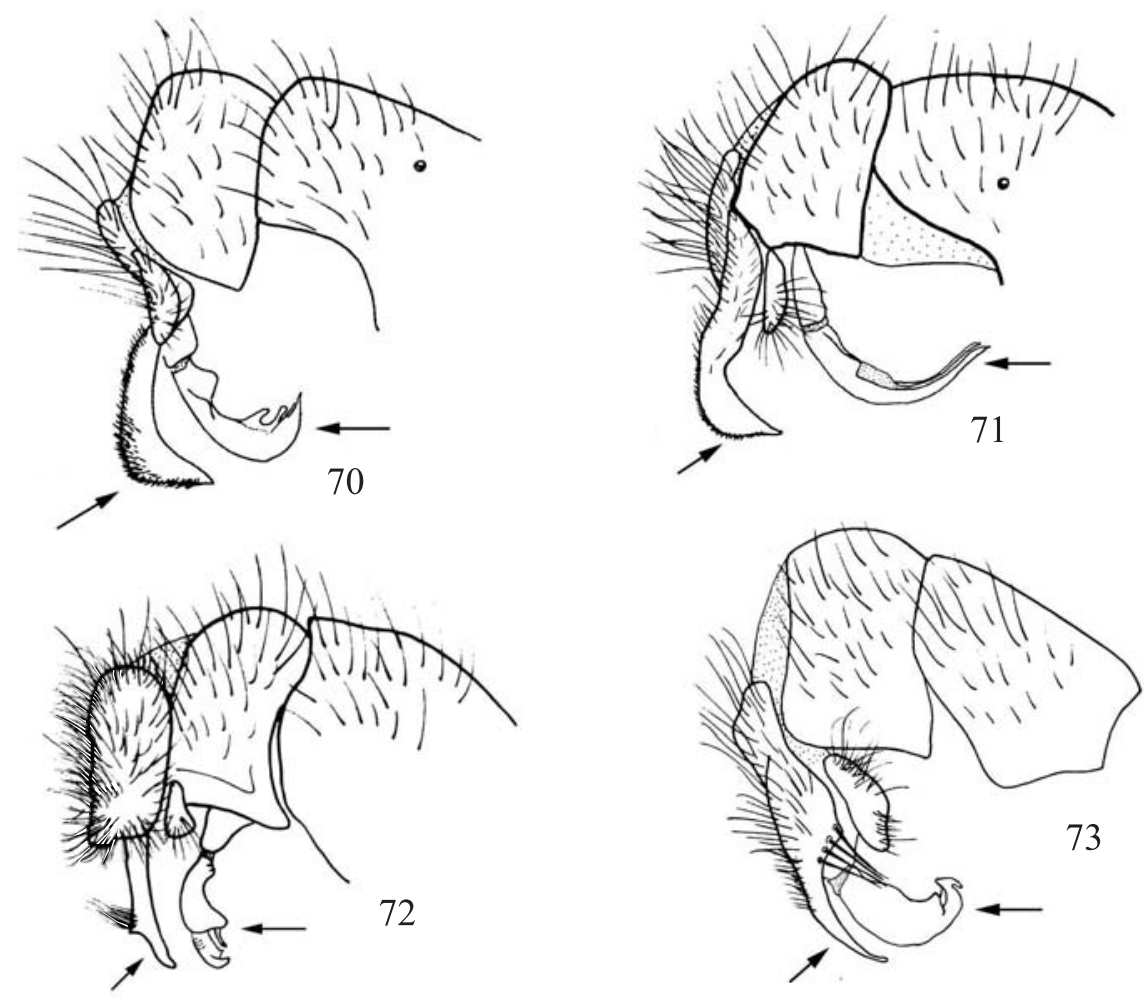

Figs. 70-73. Male terminalia: 70, Peckia (Euboettcheria) anguilla (Curran \& Walley); 71, P. (E.) australis Townsend; 72, P. (E.) collusor (Curran \& Walley); 73, P. (E.) florencioi (Prado \& Fonseca).

Phallus short, distiphallus broadly membranous with juxta small and bifid, like a pair of short or long, fingerlike appendages (Fig. 66)

Engelimyia [included species: E. inops (Walker)]

11. Antenna with first flagellomere yellowish or orange. Phallus (Fig. 67) .... Sarcophaga (Liopygia) [included species: $S$. (L.) ruficornis (Fabricius)

Antenna with first flagellomere and other segments gray or at least brown-reddish 12

12. Phallus with small basiphallus, distiphallus with a conspicuous juxta directed forward and a large ventral projection (Fig. 68) ..... Sarcophaga (Bercaea) [included species: $S$. (B.) africa (Wiedemann) (= Bercaea cruentata (Meigen) and B. haemorrhoidalis Fallen]

Phallus not as above 13

13. Medium size specimens. Scutellum with white lateral setulae. Cercus black with slightly broad and rounded apex (Fig. 69) Titanogrypa (Cuculomyia) [included species: T. (C.) larvicida (Lopes)]

Medium to robust specimens. Scutellum without white lateral setulae. Cercus not strongly dark, mostly reddish brown, with acute and/or bent apex .. 14
14. Four marginal scutellar setae (including the apical). Phallus sharp and tube-like. Cercus strongly bent forward (Figs. 70-73) Peckia (Euboettcheria) [included species: $P$. (E.) anguilla (Curran \& Walley), $P$. (E.) australis Townsend, $P$. (E.) collusor (Curran \& Walley), P. (E.) florencioi (Prado \& Fonseca)]

Three marginal scutellar setae (including the apical). Phallus well-developed not tube-like. Cercus variable 15

15. Cercus with apex abruptly bent forward. Distiphallus extremely large in ventral view (Figs. 74-77)

Peckia (Pattonella) [included species: $P .(P$. intermutans (Walker), $P$. (P.) resona (Lopes), P. (P.) smarti (Lopes), $P$. ( $P$.) pallidipilosa (Curran \& Walley)]

Cercus with conspicuous medial bend, apex strongly bent backwards. Distiphallus with a large and ventral terminal sperm-exit (Fig. 78) Blaesoxipha (Gigantotheca) [included species: B. (G.) plinthopyga (Wiedemann) (= Hystricocnema plinthopyga)]

Drosophilidae

A worldwide family of about 3000 species, with 694 species in 26 genera in the Neotropical region (Amorim et al. 2002). Drosophilid larvae are quite variable. Adults are small to medium flies. Around 50\% of all known species are in the genus Drosophila Fallén (divided into nine subgenera). 

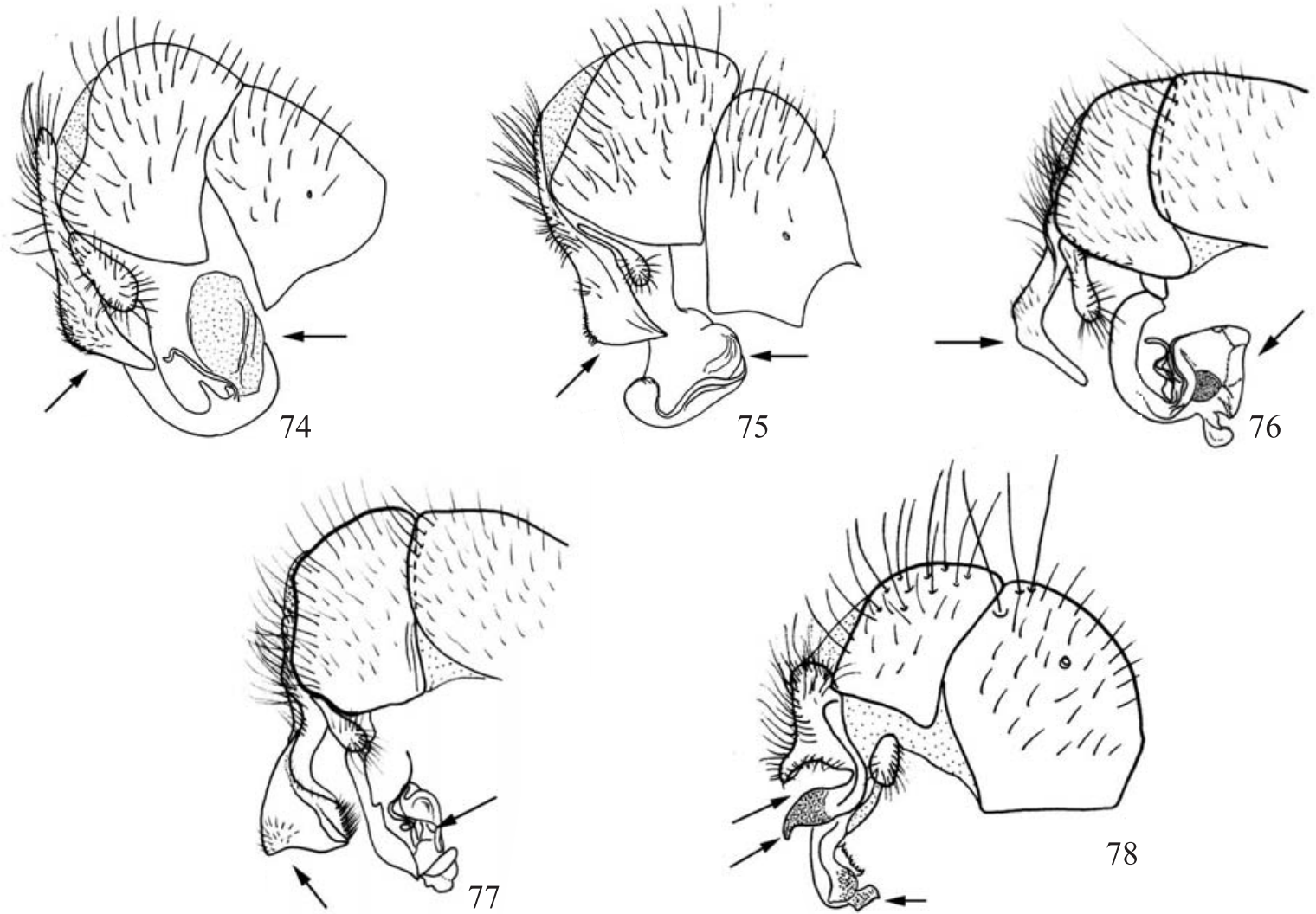

Figs. 74-78. Male terminalia: 74, Peckia (Pattonella) intermutans (Walker); 75, Peckia (Pattonella) resona (Lopes); 76, P. (P.) smarti (Lopes); 77, P. (P.) pallidipilosa (Curran \& Walley); 78, Blaesoxipha (Gigantotheca) plinthopyga (Wiedemann).

Moura et al. (1997) on rat carcasses, found one species each of D. tripunctata group, D. cannalinea group and Stegana Meigen in southern Brazil. Carvalho et al. (2000) collected drosophilids in pig corpses.

\section{Sphaeroceridae}

Cosmopolitan with about 1500 species (Thompson 2006), 174 species in 15 genera are Neotropical. Adults are small to medium flies ranging of 0.9 to $5 \mathrm{~mm}$ in length. Adults are easy to identify due to their very characteristic first, short and thick tarsomere on the hind leg (Fig. 15). They are frequently found in faeces of several mammals. Mostly of larvae are reared in organic material in decay.

Poecilossomella sp. and Archiborborus sp. have been found on rat carcass on southern Brazil (Moura et al. 1997).

\section{Sepsidae}

This cosmopolitan family has 240 described species in 24 genera (Silva 1990), of which 26 species and five genera are Neotropical (Amorim et al. 2002). Adults are very peculiar flies with usually elongated abdomens that are basally constricted, ant-like in shape (Fig. 17). They are small to medium flies, all species of which are very similar in appearance. Species are frequently found in faeces, flour, near ants and in decay organic material including carcasses (Silva 1992).
Sepsidae have been collected in Campinas, Brazil (Souza \& Linhares 1997), and Palaeosepsis maculata (Duda) and Archisepsis armata (Schiner) were found on rat carcass (Moura et al. 1997) in southern Brazil. Sepsis spp. have been found on pig carcasses (Carvalho et al. 2000).

Piophilidae (including Thyreophoridae)

This family is cosmopolitan with 77 species (Thompson 2006), and species richness is greater in the northern hemisphere in temperate and boreal regions. Four species are found in the Neotropical region (Amorim et al. 2002). Adults are small $(2.5-4.5 \mathrm{~mm})$.

Piophila casei (Linnaeus) is found throughout South America and are found in cadavers during the later stages of decomposition (Carvalho et al. 2000; Oliveira-Costa 2003). Larvae exhibit an unusual behavior - a lateral "jump" that may be for escape, or to move to other substrates, perhaps to pupate. Bocainamyia necrophila Albuquerque was found in a dried monkey carcass in higher elevations of southeastern Brazil (Albuquerque 1953).

\section{Ulidiidae (Otitidae)}

With 662 species (Thompson 2006), this family is found worldwide, including 286 species in 63 genera in the Neotropical region (Amorim et al. 2002). Adults range from 3-10 $\mathrm{mm}$. The 
life histories of the species in this family are very diverse, with mostly saprophagous, but some phytophagous species.

A variety of species have been collected in carcasses (Souza \& Linhares 1997; Carvalho et al. 2000), including rats (Acrosticta sp. and Xanthocrona sp., Monteiro-Filho \& Penereiro 1987).

Acknowledgements. We would like to thank the Conselho Nacional de Desenvolvimento Científico e Tecnológico (CNPq) (CJBC - process number 302454/2005-5) and Fundação Carlos Chagas Filho de Amparo a Pesquisa (FAPERJ) (CAMP - process number E- 26/170.119/04) for the support provided. To José Albertino Rafael and Elaine Della Giustina Soares for helpful and valuable comments on the manuscript and to Beatriz Ern da Silveira for checking the key to the Calliphoridae. To Marco Villacorta for sharing his data of flies in human corpses in Peru. To James J. Roper for improving the English. Maria de Fátima S. Zagonel and Mariza Bortolanza inked most of figures. This is the contribution number 1686 of the Department of Zoology of the Universidade Federal do Paraná.

\section{REFERENCES}

Albuquerque, D. de O. 1953. Sobre um gênero e uma espécie nova de "Thyreophoridae" do Brasil (Diptera, Haplostomata). Revista Brasileira de Biologia 13: 109-112.

Albuquerque, D. de O.; D. Pamplona \& C. J. B. de Carvalho. 1981. Contribuição ao conhecimento dos Fannia R.-D., 1830 da região neotropical (Diptera, Fanniidae). Arquivo do Museu Nacional do Rio de Janeiro 56: 9-34.

Amorim, D. de S.; V. C. Silva \& M. I. P. A. Balbi. 2002. Estado do conhecimento dos Diptera neotropicais, p. 29-36. In: C. Costa; S. A. Vanin; J.M. Lobo \& A. Melic (eds.), Proyecto de Red Iberoamericana de Biogeografia y Entomologia Sistemática PrIBES. Zaragoza: Sociedad Entomológica Aragonesa \& Cyted.

Barreto, M.; M. E. Burbano \& P. Barreto. 2002. Flies (Calliphoridae, Muscidae) and beetles (Silphidae) from human cadavers in Cali, Colombia. Memórias do Instituto Oswaldo Cruz 97: 137138.

Baumgartner, D. \& G. Greenberg. 1985. Distribution and Medical Ecology of the Blow Flies (Diptera: Calliphoridae) of Peru. Annals of the Entomological Society of America 78: 565-587.

Carvalho, C. J. B. de. 2002. Preface, p. 7-9. In: C. J. B. de Carvalho (ed.). Muscidae (Diptera) of the Neotropical Region: Taxonomy. Curitiba: Editora Universidade Federal do Paraná.

Carvalho, C. J. B. de \& M. S. Couri. 2002. Part I. Basal groups, p. 17259. In: C. J. B. de Carvalho (ed.). Muscidae (Diptera) of the Neotropical Region: Taxonomy. Curitiba: Editora Universidade Federal do Paraná.

Carvalho, C. J. B. de; M. S. Couri; A. C. Pont; D. M. Pamplona \& S. M. Lopes. 2005. A Catalogue of the Muscidae (Diptera) of the Neotropical Region. Zootaxa 860: 1-282.

Carvalho, C. J. B. de; M. O. Moura \& P. B. Ribeiro. 2002. Chave para adultos de dípteros (Muscidae, Fanniidae, Anthomyiidae) associados ao ambiente humano no Brasil. Revista Brasileira de Entomologia 46: 107-114.

Carvalho, C. J. B. de; A. C. Pont; M. S. Couri \& D. Pamplona. 2003. A Catalogue of the Fanniidae (Diptera) of the Neotropical Region. Zootaxa 219: 1-32.

Carvalho, C. J. B. de \& P. B. Ribeiro. 2000. Chave de identificação das espécies de Calliphoridae (Diptera) do sul do Brasil. Revista Brasileira de Parasitologia 9: 169-173.

Carvalho, L. M. L. \& A. X. Linhares. 2001. Seasonality of insect succession and pig carcass decomposition in a natural Forest area in southeastern Brazil. Journal of Forensic Sciences 46: 604608.

Carvalho, L. M. L.; P. J. Thyssen; A. X. Linhares \& F. A. B. Palhares.
2000. Checklist of arthropods associated with pig carrion and human corpses in Southeastern Brazil. Memórias do Instituto Oswaldo Cruz 95: 135-138.

Couri, M. S. 2005. An illustrated key to adult males of Neotropical Fannia Robineau-Desvoidy belonging to pusio sub-group (Diptera, Fanniidae). Brazilian Journal of Biology 65: 625-629.

Couri, M. S. \& C. J. B. de Carvalho. 2002. Part II. Apical groups, p. 133-287. In: C.J.B. de. Carvalho (ed.). Muscidae (Diptera) of the Neotropical Region: Taxonomy. Curitiba: Editora Universidade Federal do Paraná.

Dear, J. P. 1985. A revision of the New World Chrysomyini (Diptera: Calliphoridae). Revista Brasileira de Zoologia 3: 109-169.

Greenberg, B. \& M. L. Szyska. 1984. Immature stages and biology of fifteen species of Peruvian Calliphoridae (Diptera). Annals of the Entomological Society of America 77: 488-517.

Greenberg, B. 1991. Flies as Forensic Indicators. Journal of Medical Entomology 28: 565-577.

Greenberg, B. \& J. D. Wells. 1998. Forensic use of Megaselia abdita and M. scalaris (Phoridae: Diptera): case studies, development rates, and eggs structure. Journal of Medical Entomology 35: 205209.

Guimarães, J. H. \& N. Papavero. 1999. Myiasis in man and animals in the Neotropical region. Bibliographical database. São Paulo: Ed. Plêiade, FAPESP.

Jiron, L. F.; L. G. Vargas \& E. Vargas-Alvarado. 1983. Four muscoid flies (Sarcophagidae and Muscidae) associated with human cadavers in Costa Rica. Brenesia 21: 3-5.

James, M. T. 1973. Family Stratiomyidae, vol. 26. In: A catalogue of the Diptera of the Americas South of the United States. São Paulo: Museu de Zoologia, Universidade de São Paulo.

Lopes, H. S. 1943. Contribuição ao conhecimento de larvas de Sarcophagidae com especial referência ao esqueleto cefálico (Diptera). Memórias do Instituto Oswaldo Cruz 38: 127136.

Lopes, H. S. 1982. The importance of the mandible and clypeal arch of the first instar larvae in the classification of the Sarcophagidae. Revista Brasileira de Entomologia 26: 293-326.

Mariluis, J. C. 1982. Contribución al conocimiento de las Calliphoridae de la Argentina. Opera Lilloana 33: 3-59.

McAlpine, J. F. 1981. Morphology and terminology - adults, p. 9-63. In: J. F. McAlpine; B. V. Peterson; G. E. Shewell; H. J. Teskey; J. R Vockeroth \& D. M. Wood (eds.). Manual of Nearctic Diptera. Vol. 1. Monograph 27. Research Branch Agriculture Canada.

Mello, R. P. de. 2003. Chave para a identificação das formas adultas das espécies da família Calliphoridae (Diptera, Brachycera, Cyclorrhapha) encontradas no Brasil. Entomologia y Vectores 10: $255-268$.

Monteiro-Filho, E. L. de A. \& J. L. Penereiro. 1987. Estudo de decomposição e sucessão sobre uma carcaça animal numa área do estado de São Paulo, Brazil. Revista Brasileira de Biologia 47: $289-295$

Moura, M. O. 2004. Variação espacial como mecanismo promotor da coexistência em comunidades de insetos necrófagos. Revista Brasileira de Zoologia 21: 409-419.

Moura, M. O.; C. J. B. de Carvalho \& E. L. A. Monteiro-Filho. 1997. A preliminary analysis of insects of Medico-legal importance in Curitiba, State of Paraná. Memórias do Instituto Oswaldo Cruz 92: $269-274$.

Moura, M. O.; C. J. B. de Carvalho \& E. L. A. Monteiro-Filho. 2005. Estrutura de comunidades necrófagas: efeito da partilha de recursos na diversidade. Revista Brasileira de Zoologia 22: 1134-1140.

Oliva, A. 2001. Insects of forensic significance in Argentina. Forensic Science International 120: 145-154.

Oliveira-Costa, J. 2003. Entomologia forense; quando os insetos são os vestígios. Campinas: Millennium Editora.

Oliveira-Costa, J.; C. A. Mello-Patiu \& S. M. Lopes 2001. Dípteros muscóides associados com cadáveres humanos na cena da morte no estado do Rio de Janeiro, Brasil. Boletim do Museu Nacional, nova série, Zoologia, 464: 1-6.

Oliveira-da-Silva A; R. Ale-Rocha \& J. A. Rafael. 2006. Bionomia dos 
estágios imaturos de duas espécies de Peckia (Diptera, Sarcophagidae) em suíno em decomposição em área de floresta no norte do Brasil. Revista Brasileira de Entomologia 50: 524-527.

Pape, T., 1996. Catalogue of Sarcophagidae of the World (Insecta, Diptera). Memoirs on Entomology, International 8: 1-558.

Pape, T.; G. Dahlem; C. A. Mello-Patiu \& M. Giroux. 2006. The World of Flesh Flies (Diptera: Sarcophagidae). Retrieved January 15, 2007. Web site: http://www.zmuc.dk/entoweb/sarcoweb/ sarcweb/sarc_web.htm.

Pont, A. C. 1974. Family Anthomyiidae, vol. 96a. In: A Catalogue of the Diptera of the Americas South of the United States. São Paulo: Museu de Zoologia, Universidade de São Paulo.

Pujol-Luz, J. R.; H. Marques; A. Ururahy-Rodrigues; J. A. Rafael; F. H. A. Santana; L. C. Arantes \& R. Constantino. 2006. A Forensic Entomology case from Amazon rain forest of Brazil. Journal of Forensic Sciences 51: 1-3.

Queiroz, S. M. P. \& C. J. B. de Carvalho. 1987. Chave pictórica e descrições de larvas de 3o. ínstar de Diptera (Calliphoridae, Muscidae e Fanniidae) em vazadouros de resíduos domésticos em Curitiba, Paraná. Anais da Sociedade Entomológica do Brasil 16: 265288.

Ribeiro, P. B. \& C. J. B. de Carvalho. 1998. Pictorial key to Calliphoridae genera (Diptera) in southern Brazil. Brazilian Journal of Veterinary Parasitololgy 7: 137-140.

Roback, S. S. 1954. The evolution and taxonomy of the Sarcophaginae (Diptera, Sarcophagidae). Illinois Biological Monograph 23: $1-181$.

Salviano, R. J.; R. P. de Mello; R. de F. S. Santos; L. C. N. H. Beck \& A. Ferreira. 1996. Calliphoridae (Diptera) associated with human corpses in Rio de Janeiro, Brazil. Entomologia y Vectores 3: $145-146$.
Silva, V. C. 1990. Revision of the family Sepsidae of the Neotropical Region. I. The genus Meroplius Rondani (Diptera, Schizophora). Revista Brasileira de Entomologia 34: 709-711.

Silva, V. C. 1992. Revision of the family Sepsidae of the Neotropical Region. II. The genus Meropliosepsis Duda, 1926 (Diptera, Schizophora). Revista Brasileira de Entomologia 36: 549552.

Shewell, G. E. 1987. Sarcophagidae, p. 1159-1186. In: J. F. McAlpine; B. V. Peterson; G. E. Shewell; H. J. Teskey; J. R Vockeroth \& D. M Wood (eds.). Manual of Nearctic Diptera. Vol. 2. Agriculture Canada Monograph, 28.

Skidmore, P. 1985. The biology of the Muscidae of the world. Series Entomologica 29: 1-550.

Smith, K. G. V. 1986. A Manual of Forensic Entomology. Ithaca: Comstock Publishing Associates.

Souza, A. M. \& A. X. Linhares. 1997. Diptera and Coleoptera of potential forensic importance in southeastern Brazil: relative abundance and seasonality. Medical and Veterinary Entomology 11: $8-12$.

Thompson, F. C. 2006. Nomenclator Status Statistics. Retrieved January, 10, 2007, from The Diptera site. The BioSystematic Database of World Diptera. Web site: http://www.sel.barc.usda.gov/ Diptera/names/Status/bdwdstat.htm

Thompson, F. C. \& A. C. Pont. 1994. Systematic Database of Musca Names (Diptera). Koenigstein: Koelyz Scientific Books.

Turner, B. D. 1991. Forensic Entomology. Forensic Science Progress 5: $129-151$

Wells, J. D. \& F. A. H. Sperling. 1999. Molecular phylogeny of Chrysomya albiceps and C. rufifacies (Diptera: Calliphoridae). Annals of the Entomological Society of America 36: 222 226.

Received 28/03/2008; accepted 07/07/2008 